\title{
22. QUATERNARY OXYGEN ISOTOPE RECORD OF PELAGIC FORAMINIFERS: SITE 806, ONTONG JAVA PLATEAU ${ }^{1}$
}

\author{
W.H. Berger, ${ }^{2}$ T. Bickert, ${ }^{3}$ H. Schmidt, ${ }^{3}$ and G. Wefer ${ }^{3}$
}

\begin{abstract}
We present an oxygen isotope record that can serve as a new standard for Quaternary chronology in the western Pacific. The record is not entirely without problems. A coring gap misses Isotope Stage 19, which contains the Brunhes/Matuyama boundary. We bridged the gap by importing the corresponding portion of the record from adjacent Hole 805C. By counting the cycles related to obliquity, within the completed $\delta^{18} \mathrm{O}$ record, we date the Brunhes/Matuyama boundary at $792 \mathrm{ka}( \pm 10 \mathrm{k} . \mathrm{y}$.), in excellent agreement with previous estimates based on tuning to astronomical signals and with recent radiometric determinations. Thus, the conventional age of $730 \mathrm{ka}$ for this boundary should be abandoned.

The major feature of the record is the appearance of a strong component in the band centered on $100 \mathrm{k} . \mathrm{y} .$, near $900 \mathrm{ka}$. At this time, the obliquity-dominated fluctuations give way to eccentricity-dominated fluctuations (whereas precession-related signals remain insignificant throughout). It is not necessary to call for a sudden event at the position of the main change; instead, superposition of long cycles is sufficient cause. Nevertheless, the break in the character of the cyclicity of the record is very clear; we put it at $918 \mathrm{ka}$, at the entrance to glacial Isotope Stage 22 (mid-Pleistocene climate revolution [MPR]). The change in response of the climate system to astronomic forcing apparently is not accompanied by distinct changes in the trends of sedimentation rates. Sand content increases and carbonate decreases, on the whole, after the mid-Pleistocene climate shift. We suggest that this is a result of increased winnowing during glacial periods.
\end{abstract}

\section{INTRODUCTION}

Studies of sediments from Ontong Java Plateau in the western equatorial Pacific have contributed importantly to the stable isotope stratigraphy of the Quaternary (Shackleton and Opdyke, 1973, 1976; Schiffelbein, 1984; Hebbeln et al., 1990; Wu and Berger, 1991; Whitman and Berger, 1992). However, a complete undisturbed record of the Quaternary has not been available heretofore. During Ocean Drilling Program (ODP) Leg 130 (Kroenke, Berger, Janecek, et al., 1991), advanced hydraulic piston coring (APC) was used to retrieve undisturbed Neogene sections on the northern flank of the plateau (Fig. 1). Among these, we selected the first five cores from Hole 806B $\left(0^{\circ} 19.11^{\prime} \mathrm{N}, 159^{\circ} 21.69^{\prime} \mathrm{E}, 2520 \mathrm{~m}\right)$ for detailed study of the Quaternary. These cores (130-806B-1H through -5H) comprise the upper $44.5 \mathrm{~m}$ of sediment, which consists of calcareous ooze with well-preserved foraminifers and nannofossils.

Our goal is to provide an oxygen isotope stratigraphy for the Quaternary in the western equatorial Pacific that is essentially complete and unaffected by carbonate dissolution.

Site 806 is well above the regional lysocline (located at about $3300 \mathrm{~m}$; Berger et al., 1982; Wu and Berger, 1991), and it is also deep enough to stay above shallow positions of the lysocline, during reglaciation ( $2600 \mathrm{~m}$; Wu et al., 1991; see also Hebbeln et al., 1990; Grötsch et al., 1991). Fragmentation shows fluctuations even at this shallow depth (and yet shallower; Le and Shackleton, 1992), demonstrating that dissolution effects cannot be excluded altogether. However, we think that interference of carbonate dissolution with the isotopic record is negligible at the low proportions of fragmentation observed. Also, much winnowing is seen near the top of the plateau (Wu and Berger, 1991), but we think it does not affect the isotopic record of Site 806, which is based on coarse sand particles. Winnow-

\footnotetext{
${ }^{1}$ Berger, W.H., Kroenke, L.W., Mayer, L.A., et al., 1993. Proc. ODP, Sci. Results, 130: College Station, TX (Ocean Drilling Program).

${ }^{2}$ Geological Research Division, Scripps Institution of Oceanography, University of California, San Diego, La Jolla, CA 92093, U.S.A.

${ }^{3}$ Fachbereich Geowissenschaften, Universităt Bremen, Postfach 330440, D-2800 Bremen 33, Federal Republic of Germany,
}

ing could affect sedimentation rates, however, through alternations of mechanical removal and addition.

The fact that the Ontong Java Plateau is far from the disturbing influences of continental margins, and has a climate with minimal seasonality and interannual variability, is highly favorable for the purpose of providing a standard isotopic record. The sedimentation rate (about $20 \mathrm{~m} / \mathrm{m}$.y.) is adequate for the resolution here attempted.

We aim to obtain an age scale independent of preexisting ones. Quaternary time scales are heavily dependent on the assigned age of the Brunhes/Matuyama boundary. The recently current value of this age (730 ka; Imbrie et al., 1984; Ruddiman et al., 1986, 1989; Williams et al., 1988; Raymo et al., 1990) has been put into doubt by several proposals to increase it substantially, based on spectral analysis of oxygen isotope records (Johnson, 1982; Shackleton et al., 1990) and new results from radiometric dating (Izett et al., 1988; Izett and Obradovich, 1991; Baksi et al., 1992). As we shall show, our results indeed support an age for the Brunhes/Matuyama boundary that is $8 \%$ greater than the conventional one.

\section{MATERIALS AND METHODS}

\section{Sample Preparation}

Cores $130-806 \mathrm{~B}-1 \mathrm{H}$ through $-5 \mathrm{H}$ were sampled at 10 -cm intervals, from near the surface to $44.5 \mathrm{mbsf}$. The cores contain white foraminifer nannofossil ooze and nannofossil ooze with foraminifers. The sediment is moderately bioturbated. Minor drilling disturbances are restricted to the uppermost $50 \mathrm{~cm}$ of Cores $130-806 \mathrm{~B}-3 \mathrm{H}$ and $-5 \mathrm{H}$.

Approximately $5 \mathrm{~g}$ of wet bulk sediment were freeze-dried for each sample, weighed, and wet-sieved at $63 \mu \mathrm{m}$. The material was ultrasonified twice for about $10 \mathrm{~s}$ during the process. The sand fraction $(>63 \mu \mathrm{m})$ was dried in an oven at $50^{\circ} \mathrm{C}$ for $40 \mathrm{hr}$, and then weighed again to determine the percent sand fraction.

For each sample, 25 tests of the planktonic foraminifers Globigerinoides sacculifer and Pulleniatina obliquiloculata (and its immediate ancestors) were picked in the $355-425 \mu \mathrm{m}$ fraction, and crushed with a glass pestle. In some cases, fewer than 25 tests were available. The number of specimens (25) and the rather narrow size fraction were chosen to minimize the influence of vital effects on the isotopic ratios (Berger et al., 1978). For $G$. sacculifer, only tests that were intact 


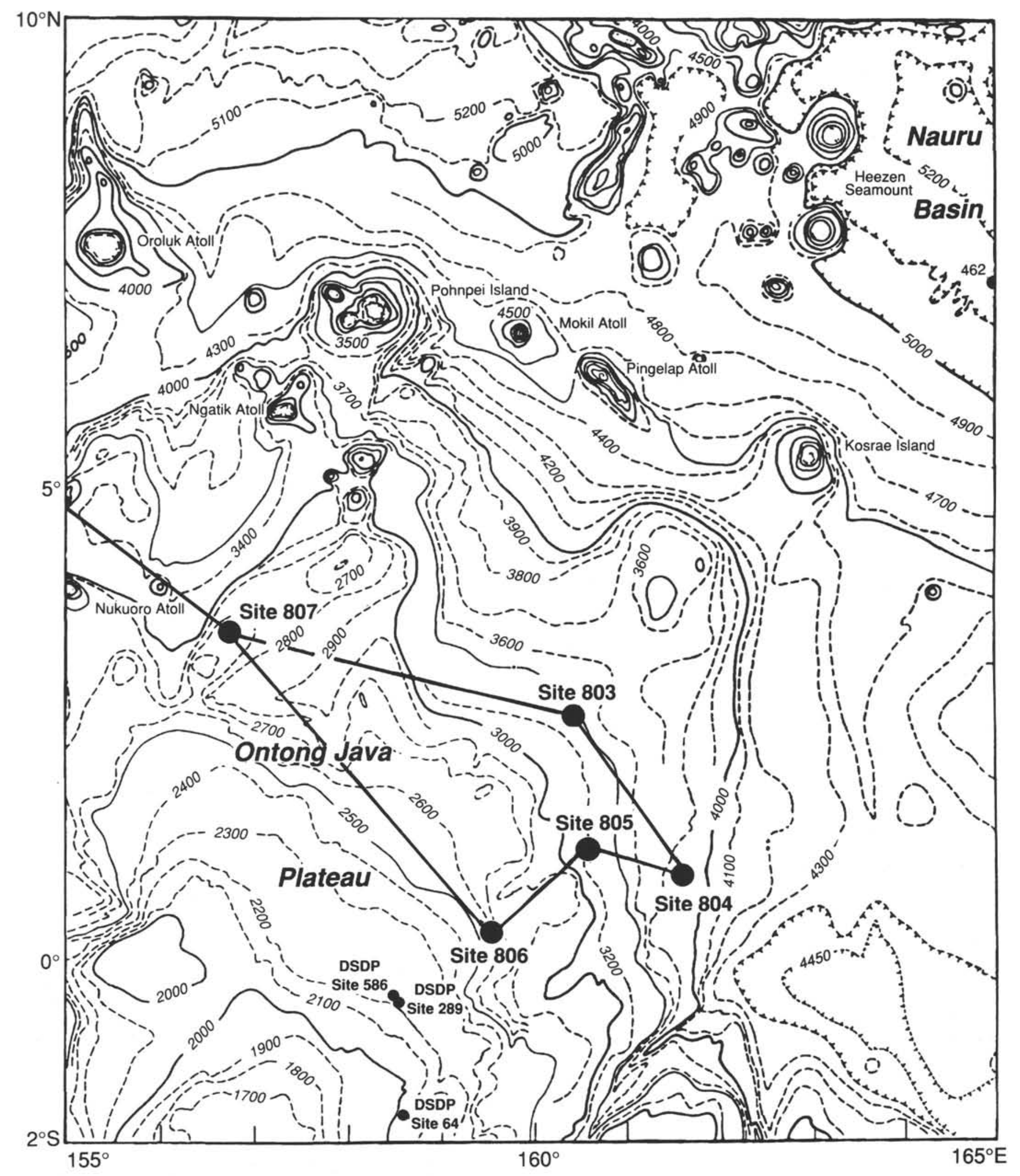

Figure 1. Track of Leg 130 on Ontong Java Plateau and position of Site 806 (from Berger et al., 1991). Contour values in meters. 


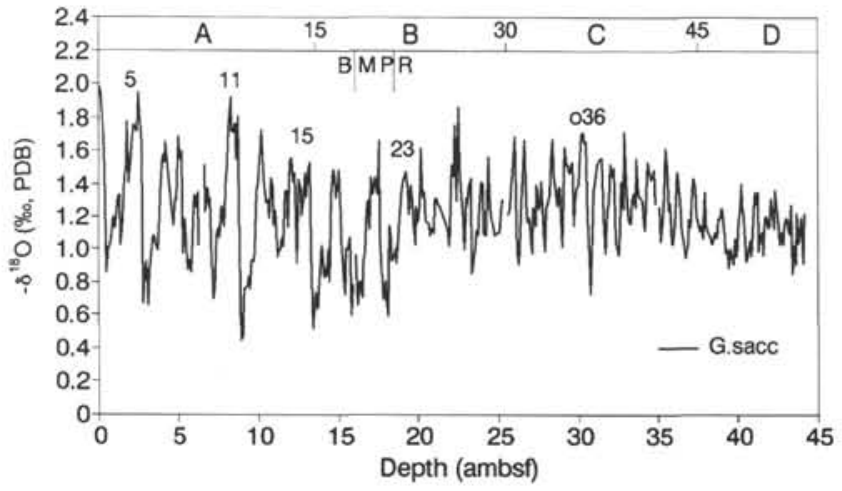

Figure 2. Overview of raw data for oxygen isotope profile of $G$. sacculifer, Cores $130-806 \mathrm{~B}-1 \mathrm{H}$ through $-5 \mathrm{H}$. Depths are adjusted for core expansions listed in Kroenke et al. (1991), as follows: 1.0, 1.03, 1.05, 1.04, and 1.05. Bar labeled "PR" marks the mid-Pleistocene climate shift, that is, the transition zone between two regimes showing contrasting character of fluctuations. Label "B/M" represents the approximate position of the Brunhes/Matuyama boundary, as inferred from the biostratigraphically determined sedimentation rate. Breaks in profile show core ends at $6.5,16,25.5$, and 35 m (driller's depths). Obliquity cycle 036 identified for orientation.

and complete with the final "sac"-chamber were selected. An effort was made to avoid G. fistulosus, where present; the immature members of the species are difficult to distinguish from mature $G$. "trilobus" (the non-"sac" phenotype of G. sacculifer). Sample size for isotopic measurements was $60-80 \mu \mathrm{g}$; the carbonate was reacted with phosphoric acid at $75^{\circ} \mathrm{C}$. Isotopic ratios were determined using a Finnigan MAT 251 micromass spectrometer with a Finnigan Automated Carbonate Device (Kiel system), at the Geoscience Department of the University of Bremen. Precision was regularly checked by running standards (Solnhofen Limestone). Over a 1-yr period (1990), standard deviations were $<0.07 \%$ for $\delta^{18} \mathrm{O}$ and $0.5 \%$ for $\delta^{13} \mathrm{C}$. Conversion to the PeeDee Belemnite (PDB) scale was performed by way of NBS Standards 18, 19, and 20.

\section{RESULTS AND DISCUSSION}

\section{Data-base Overview}

Results of the stable isotope determinations are given in Table 1 and plotted in Figures 2 and 3. The record shows the familiar fluctuations, ranging typically between $-0.7 \%$ and $-1.8 \%$ for $G$. sacculifer, and between $-0.3 \%$ and $-1.3 \%$ for the deeper living Pulleniatina in the late Quaternary. High amplitudes are visible for the most recent portion of the record down to about $18-19$ mbsf, although a decrease takes place toward the bottom of this interval. At that level, a marked change occurs in the character of the fluctuations: the amplitude is considerably reduced, and the frequency of variation is higher and more regular below this depth. The transition from one regime to the other occurs just after Isotope Stage 23. This "mid-Pleistocene Revolution" in the nature of climatic cycles is the dominating feature of the record (marked PR in Fig. 2). It occurs $2-3 \mathrm{~m}$ below the inferred position of the Brunhes/Matuyama boundary (marked BM in Fig. 2). Based on the estimated sedimentation rate of $20 \mathrm{~m} / \mathrm{m}$.y. (Shipboard Scientific Party, 1991, p. 323), the boundary should appear near $15 \mathrm{~m}$, that is, in the lowermost part of Core 130-806B-2H. In fact, as we shall show by correlation with Hole $805 \mathrm{C}$, it occurs in the break between Cores $130-806 \mathrm{~B}-2 \mathrm{H}$ and $-3 \mathrm{H}$, and the Isotope Stage 19 is missing. The magnetic measurements did not unequivocally locate the boundary in Site 806 because of deterioration of the signal from chemical reactions related to sulfate reduction (Shipboard Scientific Party, 1991, pp. 317-320).

The overall patterns demonstrated by these results have been known for some time; they are clearly reflected in the profile given
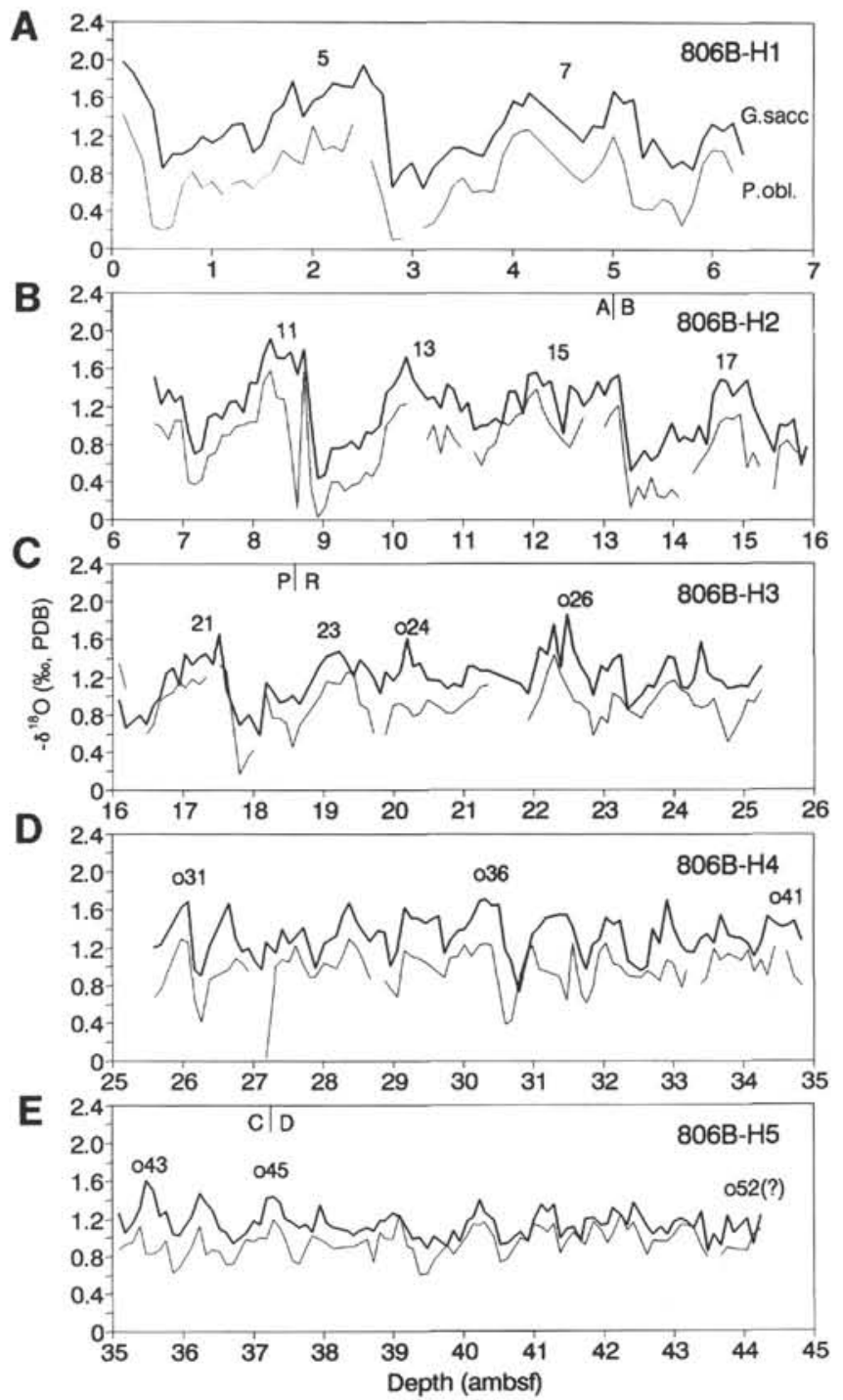

Figure 3. Raw data for oxygen isotope profiles of $G$. sacculifer and Pulleniatina for Cores 130-806B-1H through -5H (in panels labeled A through E). Depths are adjusted for core expansion, with core tops set at driller's depths (see legend for Fig. 2). Numbers on top of curves are the isotope stages of Emiliani (1955) and Shackleton and Opdyke (1973). Labels "A/B" (Fig. 3B) and "C/D" (Fig. 3E) mark the inferred positions of obliquity cycles 015 and 045 , respectively; "B/C" (o30) is inferred to be in the break between Cores $130-806 \mathrm{~B}-3 \mathrm{H}$ to $-4 \mathrm{H}$. These boundaries divide the Quaternary into three major intervals $(\mathrm{A}, \mathrm{B}$, and $\mathrm{C})$ that have different climatic frequencies and amplitude characteristics. Bar labeled "PR" marks the mid-Pleistocene Revolution (as in Fig. 2).

in Shackleton and Opdyke (1976) for Core V28-239 from the Ontong Java Plateau. In the conventional time scale, the age of the mid-Pleistocene climate shift (PR in Figs. 2 and 3 ) is given as $840 \mathrm{ka}$ or so (see Raymo et al., 1990, their fig. 2a, oxygen isotope record for Site 677). This shift occurs at $18.5 \mathrm{~m}$ in Hole 806B. Thus, based on these data, our first rough estimate of sedimentation rate is $18.5 / 0.84 \mathrm{~m} / \mathrm{m}$.y. (i.e., $22 \mathrm{~m} / \mathrm{m} . \mathrm{y}$.). This estimate is in excellent agreement with the shipboard assessment of $20 \mathrm{~m} / \mathrm{m}$.y. based on the biostratigraphy (Shipboard Scientific Party, 1991).

\section{Major Trends in Means and Ranges}

The major trends of the oxygen isotope fluctuations are readily extracted by comparing means and standard deviations for the values 
Table $1 . \delta^{18} \mathrm{O}$ values for $G$. sacculifer and Pulleniatina for Cores $130-806 \mathrm{~B}-1 \mathrm{H}$ to $-5 \mathrm{H}$.

\begin{tabular}{|c|c|c|c|c|c|c|c|c|}
\hline $\begin{array}{l}\text { Depth } \\
\text { (mbsf) }\end{array}$ & $\begin{array}{c}\text { G. sacculifer } \\
\delta^{18} \mathrm{O} \\
(\% \circ, \mathrm{PDB})\end{array}$ & $\begin{array}{c}\text { Pulleniatina } \\
\delta^{18} \mathrm{O} \\
(\% o, \mathrm{PDB})\end{array}$ & $\begin{array}{l}\text { Depth } \\
\text { (mbsf) }\end{array}$ & $\begin{array}{c}\text { G. sacculifer } \\
\delta^{18} \mathrm{O} \\
(\%, \mathrm{PDB})\end{array}$ & $\begin{array}{c}\text { Pulleniatina } \\
\delta^{18} \mathrm{O} \\
(\%, \text { PDB })\end{array}$ & $\begin{array}{l}\text { Depth } \\
\text { (mbsf) }\end{array}$ & $\begin{array}{c}\text { G. sacculifer } \\
\delta^{18} \mathrm{O} \\
(\%, \mathrm{PDB})\end{array}$ & $\begin{array}{c}\text { Pulleniatina } \\
\delta^{18} \mathrm{O} \\
(\% \circ, \mathrm{PDB})\end{array}$ \\
\hline \multirow{2}{*}{\multicolumn{3}{|c|}{$130-806 \mathrm{~B}-1 \mathrm{H}$}} & 7.70 & -1.25 & -0.89 & 15.40 & -1.21 & -0.71 \\
\hline & & & 7.80 & -1.27 & -0.99 & 15.49 & -1.05 & -0.56 \\
\hline 0.10 & -1.98 & -1.44 & 7.90 & -1.14 & -1.01 & 15.60 & -0.89 & -0.16 \\
\hline 0.20 & -1.86 & -1.19 & 7.99 & -1.46 & -1.04 & 15.70 & -0.72 & -0.32 \\
\hline 0.30 & -1.68 & -0.94 & 8.10 & -1.44 & -1.04 & 15.78 & -1.01 & -0.78 \\
\hline 0.40 & -1.48 & -0.24 & 8.20 & -1.73 & -1.46 & 15.90 & -1.00 & -0.85 \\
\hline 0.50 & -0.85 & -0.20 & 8.30 & -1.92 & -1.58 & 16.00 & -1.07 & -0.75 \\
\hline 0.60 & -1.01 & -0.22 & 8.40 & -1.72 & -1.29 & 16.10 & -0.97 & -0.68 \\
\hline 0.70 & -1.01 & -0.68 & 8.50 & -1.71 & -1.28 & 16.18 & -0.78 & -0.70 \\
\hline 0.80 & -1.07 & -0.82 & 8.60 & -1.77 & -0.81 & & & \\
\hline 0.90 & -1.20 & -0.65 & 8.70 & -1.55 & -0.12 & $130-806 \mathrm{~B}-3 \mathrm{H}$ & & \\
\hline 1.00 & -1.13 & -0.73 & 8.80 & -1.81 & -1.49 & & & \\
\hline 1.10 & -1.19 & -0.59 & 8.90 & -1.01 & -0.32 & 16.10 & -1.81 & -1.35 \\
\hline 1.20 & -1.32 & -0.70 & 9.00 & -0.44 & -0.03 & 16.20 & -1.00 & -1.08 \\
\hline 1.30 & -1.33 & -0.73 & 9.10 & -0.48 & -0.13 & 16.40 & -0.80 & -0.37 \\
\hline 1.40 & -1.03 & -0.65 & 9.20 & -0.76 & -0.40 & 16.50 & -0.70 & -0.60 \\
\hline 1.49 & -1.11 & -0.75 & 9.30 & -0.76 & -0.40 & 16.60 & -0.90 & -0.70 \\
\hline 1.60 & -1.44 & -0.83 & 9.40 & -0.78 & -0.30 & 16.70 & -0.98 & -0.96 \\
\hline 1.70 & -1.53 & -1.05 & 9.49 & -0.84 & -0.36 & 16.80 & -1.24 & -1.00 \\
\hline 1.80 & -1.78 & -0.96 & 9.60 & -0.75 & -0.40 & 16.90 & -1.30 & -1.04 \\
\hline 1.90 & -1.40 & -0.90 & 9.70 & -0.93 & -0.51 & 17.00 & -1.12 & -1.16 \\
\hline 2.00 & -1.57 & -1.31 & 9.80 & -0.93 & -0.46 & 17.08 & -1.44 & -1.09 \\
\hline 2.10 & -1.63 & -1.05 & 9.90 & -1.00 & -0.60 & 17.19 & -1.33 & -1.19 \\
\hline 2.20 & -1.76 & -1.10 & 10.00 & -1.35 & -1.00 & 17.30 & -1.41 & -1.13 \\
\hline 2.30 & -1.73 & -1.04 & 10.10 & -1.43 & -1.10 & 17.40 & -1.44 & -1.20 \\
\hline 2.40 & -1.72 & -1.33 & 10.20 & -1.54 & -1.21 & 17.49 & -1.34 & -1.20 \\
\hline 2.50 & -1.95 & -1.14 & 10.30 & -1.72 & -1.23 & 17.60 & $-1.66^{\circ}$ & -1.33 \\
\hline 2.59 & -1.77 & -0.94 & 10.40 & -1.50 & -1.16 & 17.70 & -1.07 & -1.27 \\
\hline 2.70 & -1.65 & -0.57 & 10.50 & -1.38 & -0.88 & 17.90 & -0.69 & -0.16 \\
\hline 2.80 & -0.67 & -0.10 & 10.60 & -1.29 & -0.85 & 18.03 & -0.81 & -0.36 \\
\hline 2.90 & -0.84 & -0.11 & 10.70 & -1.31 & -1.02 & 18.12 & -0.70 & -0.43 \\
\hline 2.99 & -0.93 & -0.29 & 10.80 & -1.19 & -0.70 & 18.20 & -0.59 & -0.46 \\
\hline 3.10 & -0.66 & -0.23 & 10.90 & -1.44 & -1.00 & 18.30 & -1.15 & -1.02 \\
\hline 3.20 & -0.86 & -0.27 & 10.99 & -1.38 & -0.86 & 18.39 & -1.06 & -0.77 \\
\hline 3.30 & -0.98 & -0.43 & 11.10 & -1.15 & -0.76 & 18.50 & -0.93 & -0.77 \\
\hline 3.40 & -1.08 & -0.67 & 11.20 & -1.24 & -0.81 & 18.60 & -0.95 & -0.72 \\
\hline 3.50 & -1.08 & -0.76 & 11.30 & -0.95 & -0.72 & 18.69 & -1.01 & -0.46 \\
\hline 3.60 & -1.02 & -0.60 & 11.40 & -1.00 & -0.58 & 18.80 & -0.91 & -0.69 \\
\hline 3.70 & -0.99 & -0.62 & 11.50 & -1.00 & -0.75 & 19.10 & -1.34 & -1.00 \\
\hline 3.80 & -1.20 & -0.61 & 11.60 & -1.08 & -0.80 & 19.20 & -1.42 & -1.15 \\
\hline 3.90 & -1.34 & -1.02 & 11.70 & -1.02 & -1.04 & 19.40 & -1.48 & -1.12 \\
\hline 4.00 & -1.58 & -1.20 & 11.80 & -1.36 & -1.00 & 19.50 & -1.36 & -1.25 \\
\hline 4.09 & -1.52 & -1.26 & 11.90 & -1.36 & -1.10 & 19.60 & -1.21 & -1.27 \\
\hline 4.15 & -1.66 & -1.27 & 12.00 & -1.13 & -1.15 & 19.70 & -1.39 & -0.91 \\
\hline 4.60 & -1.25 & -0.80 & 12.09 & -1.54 & -1.29 & 19.80 & -1.30 & -0.87 \\
\hline 4.70 & -1.14 & -0.72 & 12.20 & -1.56 & -1.39 & 19.90 & -1.19 & -0.61 \\
\hline 4.80 & -1.31 & -0.80 & 12.30 & -1.41 & -1.16 & 20.00 & -1.03 & -0.85 \\
\hline 4.90 & -1.30 & -0.97 & 12.40 & -1.47 & -1.01 & 20.08 & -1.26 & -0.59 \\
\hline 5.00 & -1.68 & -1.20 & 12.60 & -0.91 & -0.84 & 20.19 & -1.17 & -0.91 \\
\hline 5.10 & -1.55 & -0.94 & 12.70 & -1.43 & -0.77 & 20.30 & -1.26 & -0.93 \\
\hline 5.20 & -1.59 & -0.47 & 12.80 & -1.36 & -0.94 & 20.40 & -1.62 & -0.87 \\
\hline 5.30 & -0.98 & -0.43 & 12.90 & -1.20 & -1.09 & 20.49 & -1.32 & -0.79 \\
\hline 5.40 & -1.19 & -0.43 & 13.00 & -1.30 & -1.09 & 20.60 & -1.35 & -0.82 \\
\hline 5.50 & -1.01 & -0.54 & 13.10 & -1.47 & -1.17 & 20.70 & -1.17 & -0.96 \\
\hline 5.59 & -0.87 & -0.50 & 13.20 & -1.32 & -0.99 & 20.90 & -1.15 & -0.88 \\
\hline 5.69 & -0.94 & -0.25 & 13.30 & -1.48 & -1.13 & 21.00 & -1.08 & -0.82 \\
\hline 5.80 & -0.86 & -0.50 & 13.40 & -1.54 & -1.21 & 21.10 & -1.13 & -0.81 \\
\hline 5.90 & -1.17 & -0.91 & 13.50 & -0.99 & -0.59 & 21.22 & -1.10 & -0.90 \\
\hline 5.99 & -1.34 & -1.06 & 13.59 & -0.52 & -0.14 & 21.30 & -1.31 & -0.95 \\
\hline 6.10 & -1.26 & -1.05 & 13.70 & -0.63 & -0.35 & 21.40 & -1.31 & -1.00 \\
\hline 6.20 & -1.35 & -0.83 & 13.80 & -0.74 & -0.22 & 21.50 & -1.28 & -1.10 \\
\hline \multirow[t]{2}{*}{6.30} & -1.02 & -0.61 & 13.90 & -0.63 & -0.45 & 21.60 & -1.27 & -1.12 \\
\hline & & & 13.99 & -0.68 & -0.24 & 22.10 & -1.13 & -0.73 \\
\hline \multirow[t]{2}{*}{$130-806 \mathrm{~B}-2 \mathrm{H}$} & & & 14.10 & -0.87 & -0.24 & 22.20 & -1.02 & -0.74 \\
\hline & & & 14.20 & -1.03 & -0.32 & 22.40 & -1.52 & -0.99 \\
\hline 6.60 & -1.52 & -1.02 & 14.30 & -0.83 & -0.23 & 22.50 & -1.44 & -1.27 \\
\hline 6.70 & -1.23 & -0.99 & 14.37 & -0.88 & -0.47 & 22.60 & -1.76 & -1.44 \\
\hline 6.80 & -1.38 & -0.86 & 14.50 & -0.83 & -0.50 & 22.70 & -1.30 & -1.22 \\
\hline 6.90 & -1.26 & -1.05 & 14.60 & -1.00 & -0.59 & 22.80 & -1.87 & -1.08 \\
\hline 7.00 & -1.31 & -1.05 & 14.70 & -0.80 & -0.71 & 22.90 & -1.50 & -0.94 \\
\hline 7.10 & -0.92 & -0.40 & 14.80 & -1.33 & -0.85 & 23.00 & -1.32 & -0.92 \\
\hline 7.20 & -0.70 & -0.37 & 14.90 & -1.49 & -1.04 & 23.12 & -1.18 & -0.84 \\
\hline 7.30 & -0.75 & -0.43 & 15.00 & -1.48 & -1.09 & 23.19 & -1.00 & -0.58 \\
\hline 7.40 & -1.08 & -0.68 & 15.09 & -1.31 & -1.06 & 23.30 & -1.32 & -0.77 \\
\hline 7.50 & -1.13 & -0.71 & 15.20 & -1.41 & -1.12 & 23.40 & -1.26 & -0.71 \\
\hline 7.60 & -1.07 & -0.90 & 15.30 & -1.49 & -0.56 & 23.49 & -1.38 & -1.03 \\
\hline
\end{tabular}


Table 1 (continued).

\begin{tabular}{|c|c|c|c|c|c|c|c|c|}
\hline $\begin{array}{l}\text { Depth } \\
\text { (mbsf) }\end{array}$ & $\begin{array}{c}\text { G. sacculifer } \\
\delta^{18} \mathrm{O} \\
(\%,, \mathrm{PDB})\end{array}$ & $\begin{array}{c}\text { Pulleniatina } \\
\delta^{18} \mathrm{O} \\
(\%, \mathrm{PDB})\end{array}$ & $\begin{array}{l}\text { Depth } \\
\text { (mbsf) }\end{array}$ & $\begin{array}{c}\text { G. sacculifer } \\
\delta^{18} \mathrm{O} \\
(\%, \mathrm{PDB})\end{array}$ & $\begin{array}{c}\text { Pulleniatina } \\
\delta^{18} \mathrm{O} \\
(\%,, \mathrm{PDB})\end{array}$ & $\begin{array}{l}\text { Depth } \\
\text { (mbsf) }\end{array}$ & $\begin{array}{c}\text { G. sacculifer } \\
\delta^{18} \mathrm{O} \\
(\% o, \mathrm{PDB})\end{array}$ & $\begin{array}{c}\text { Pulleniatina } \\
\delta^{18} \mathrm{O} \\
(\%,, \mathrm{PDB})\end{array}$ \\
\hline 23.60 & -1.44 & -0.98 & 30.70 & -1.66 & -0.76 & 37.40 & -1.44 & -1.19 \\
\hline 23.70 & -0.85 & -0.86 & 30.80 & -1.18 & -0.38 & 37.50 & -1.38 & -1.10 \\
\hline 23.90 & -1.01 & -0.76 & 30.90 & -1.06 & -0.43 & 37.58 & -1.20 & -1.00 \\
\hline 24.00 & -1.12 & -0.89 & 31.00 & -0.73 & -0.83 & 37.69 & -1.16 & -0.76 \\
\hline 24.10 & -1.09 & -0.95 & 31.12 & -1.10 & -1.14 & 37.80 & -1.11 & -0.72 \\
\hline 24.20 & -1.26 & -1.06 & 31.20 & -1.35 & -1.22 & 37.90 & -1.15 & -0.89 \\
\hline 24.30 & -1.42 & -1.14 & 31.31 & -1.43 & -0.98 & 37.99 & -1.06 & -1.02 \\
\hline 24.40 & -1.40 & -1.17 & 31.40 & -1.52 & -0.95 & 38.10 & -1.35 & -0.98 \\
\hline 24.50 & -1.10 & -1.06 & 31.60 & -1.55 & -0.89 & 38.20 & -1.16 & -0.94 \\
\hline 24.60 & -1.08 & -1.03 & 31.70 & -1.56 & -0.64 & 38.30 & -1.11 & -0.88 \\
\hline 24.69 & -1.17 & -0.90 & 31.80 & -1.41 & -1.26 & 38.50 & -1.08 & -0.90 \\
\hline 24.80 & -1.57 & -0.88 & 31.92 & -1.11 & -0.70 & 38.60 & -1.03 & -0.90 \\
\hline 24.90 & -1.25 & -0.90 & 32.00 & -0.98 & -0.61 & 38.70 & -1.08 & -0.94 \\
\hline 24.99 & -1.19 & -0.97 & 32.10 & -1.24 & -0.79 & 38.80 & -1.11 & -0.98 \\
\hline 25.10 & -1.16 & -0.72 & 32.20 & -1.29 & -1.16 & 38.90 & -1.07 & -0.74 \\
\hline 25.20 & -1.08 & -0.51 & 32.30 & -1.52 & -1.26 & 39.00 & -1.19 & -1.06 \\
\hline 25.40 & -1.11 & -0.77 & 32.40 & -1.45 & -1.03 & 39.08 & -1.19 & -0.99 \\
\hline 25.50 & -1.10 & -0.96 & 32.50 & -1.50 & -1.01 & 39.19 & -1.26 & -0.99 \\
\hline 25.60 & -1.19 & -0.93 & 32.62 & -1.06 & -0.91 & 39.30 & -1.22 & -1.25 \\
\hline \multirow[t]{2}{*}{25.70} & -1.31 & -1.05 & 32.81 & -0.96 & -0.88 & 39.40 & -1.09 & -0.91 \\
\hline & & & 32.90 & -1.01 & -0.95 & 39.49 & -0.98 & -0.88 \\
\hline \multirow[t]{2}{*}{$130-806 \mathrm{~B}-4 \mathrm{H}$} & & & 32.99 & -1.41 & -0.93 & 39.60 & -1.00 & -0.61 \\
\hline & & & 33.10 & -1.24 & -0.85 & 39.70 & -0.88 & -0.61 \\
\hline 25.60 & -1.21 & -0.67 & 33.20 & -1.71 & -1.07 & 39.80 & -1.01 & -0.75 \\
\hline 25.70 & -1.23 & -0.76 & 33.30 & -1.42 & $-1.04-$ & 40.00 & -0.90 & -0.91 \\
\hline 26.00 & -1.62 & -1.29 & 33.42 & -1.23 & -0.78 & 40.10 & -1.07 & -0.82 \\
\hline 26.10 & -1.69 & -1.26 & 33.50 & -1.16 & -0.95 & 40.20 & -0.96 & -0.90 \\
\hline 26.20 & -0.97 & -0.62 & 33.60 & -1.16 & -0.88 & 40.30 & -1.18 & -1.02 \\
\hline 26.30 & -0.91 & -0.41 & 33.70 & -1.30 & -0.82 & 40.40 & -1.22 & -1.14 \\
\hline 26.42 & -1.21 & -0.86 & 33.80 & -1.35 & -0.88 & 40.50 & -1.40 & -1.13 \\
\hline 26.70 & -1.67 & -0.98 & 33.90 & -1.26 & -1.19 & 40.57 & -1.28 & -1.16 \\
\hline 26.81 & -1.29 & -1.09 & 34.00 & -1.56 & -1.07 & 40.70 & -1.19 & -1.00 \\
\hline 26.90 & -1.17 & -1.04 & 34.12 & -1.33 & -1.13 & 40.80 & -0.92 & -0.73 \\
\hline 26.99 & -1.19 & -0.95 & 34.31 & -1.30 & -1.07 & 40.90 & -0.93 & -0.77 \\
\hline 27.10 & -1.05 & -0.63 & 34.40 & -1.25 & -1.18 & 41.10 & -1.06 & -1.00 \\
\hline 27.20 & -0.97 & -0.74 & 34.49 & -1.11 & -0.95 & 41.20 & -0.96 & -0.96 \\
\hline 27.25 & -1.26 & -0.42 & 34.60 & -1.26 & -1.07 & 41.30 & -1.18 & -1.14 \\
\hline 27.40 & -1.15 & -1.01 & 34.70 & -1.53 & -0.91 & 41.41 & -1.35 & -1.11 \\
\hline 27.50 & -1.40 & -1.08 & 34.80 & -1.47 & -1.20 & 41.50 & -1.27 & -1.05 \\
\hline 27.60 & -1.25 & -1.05 & 34.92 & -1.42 & -1.10 & 41.60 & -1.35 & -1.15 \\
\hline 27.70 & -1.32 & -1.22 & 35.00 & -1.44 & -1.16 & 41.70 & -0.99 & -0.83 \\
\hline 27.80 & -1.42 & -1.02 & 35.10 & -1.49 & -0.89 & 41.80 & -1.09 & -0.96 \\
\hline 27.91 & -1.18 & -0.88 & 35.21 & -1.28 & -0.81 & 41.90 & -1.11 & -1.05 \\
\hline 28.00 & -0.99 & -0.89 & & & & 42.00 & -0.96 & -0.96 \\
\hline 28.11 & -1.25 & -1.04 & $130-806 \mathrm{~B}-5 \mathrm{H}$ & & & 42.08 & -1.19 & -0.92 \\
\hline 28.31 & -1.33 & -0.98 & & & & 42.20 & -1.21 & -1.16 \\
\hline 28.40 & -1.55 & -1.12 & 35.10 & -1.26 & -0.88 & 42.30 & -1.13 & -1.07 \\
\hline 28.49 & -1.67 & -1.30 & 35.20 & -1.05 & -0.93 & 42.40 & -1.14 & -0.93 \\
\hline 28.60 & -1.47 & -1.21 & 35.30 & -1.16 & -0.96 & 42.49 & -1.31 & -1.03 \\
\hline 28.70 & -1.37 & -1.06 & 35.41 & -1.32 & -1.13 & 42.60 & -1.23 & -1.24 \\
\hline 28.79 & -1.27 & -0.88 & 35.50 & -1.62 & -0.82 & 42.70 & -1.12 & -1.07 \\
\hline 28.91 & -1.39 & -0.80 & 35.60 & -1.51 & -0.82 & 42.80 & -1.37 & -1.16 \\
\hline 29.00 & -1.37 & -0.86 & 35.70 & -1.23 & -0.87 & 43.00 & -1.11 & -0.80 \\
\hline 29.10 & -1.01 & -0.76 & 35.80 & -1.28 & -0.97 & 43.10 & -1.03 & -0.96 \\
\hline 29.20 & -1.17 & -0.68 & 35.90 & -1.04 & -0.62 & 43.20 & -1.11 & -0.95 \\
\hline 29.30 & -1.63 & -1.17 & 36.00 & -1.03 & -0.69 & 43.30 & -1.03 & -0.96 \\
\hline 29.41 & -1.52 & -1.12 & 36.07 & -1.11 & -0.76 & 43,40 & -1.16 & -1.02 \\
\hline 29.50 & -1.52 & -1.09 & 36.18 & -1.22 & -0.89 & 43.50 & -1.20 & -1.13 \\
\hline 29.61 & -1.47 & -1.05 & 36.30 & -1.48 & -1.13 & 43.58 & -1.16 & -1.13 \\
\hline 29.81 & -1.53 & -0.94 & 36.40 & -1.37 & -0.81 & 43.70 & -1.09 & -1.10 \\
\hline 29.90 & -1.14 & -0.88 & 36.49 & -1.30 & -0.87 & 43.80 & -1.27 & -0.90 \\
\hline 29.99 & -1.28 & -1.10 & 36.60 & -1.10 & -0.86 & 43.90 & -0.85 & -0.78 \\
\hline 30.10 & -1.38 & -1.11 & 36.70 & -1.06 & -0.72 & 43.99 & -1.03 & -0.87 \\
\hline 30.20 & -1.40 & -1.24 & 36.80 & -0.94 & -0.72 & 44.10 & -0.91 & -0.80 \\
\hline 30.30 & -1.50 & -1.10 & 37.00 & -1.05 & -0.98 & 44.20 & -1.22 & -0.89 \\
\hline 30.42 & -1.70 & -1.23 & 37.10 & -1.18 & -0.96 & 44.30 & -1.04 & -0.87 \\
\hline 30.50 & -1.72 & -1.24 & 37.20 & -1.14 & -1.00 & 44.50 & -1.19 & -0.85 \\
\hline 30.60 & -1.65 & -1.22 & 37.30 & -1.43 & -0.99 & 44.60 & -1.23 & -1.02 \\
\hline
\end{tabular}




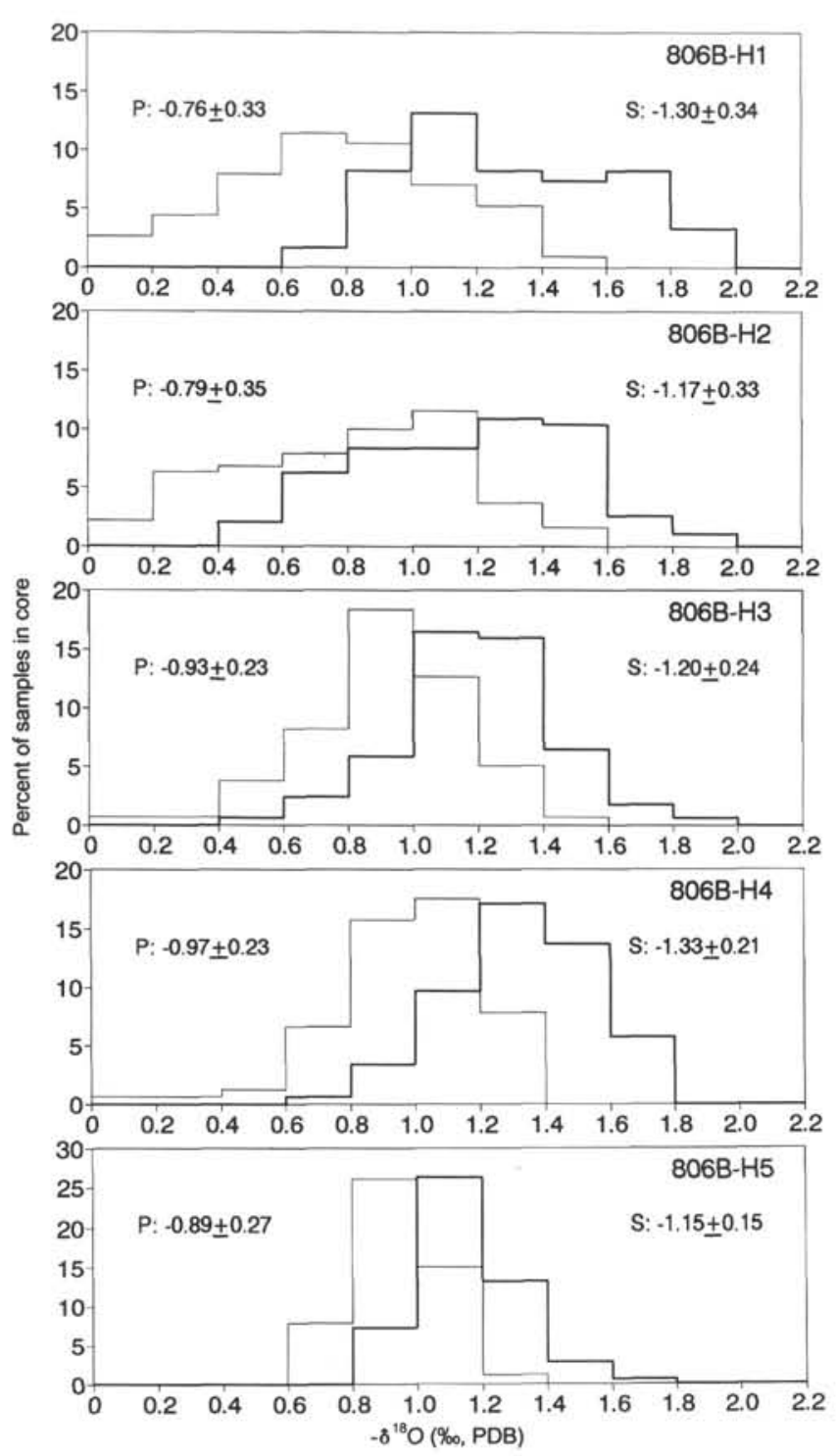

Figure 4. Histograms for distributions of $\delta^{18} \mathrm{O}$ values for $G$. sacculifer and Pulleniatina for each of the first five cores in Hole 806B. Numbers within each panel are means and standard deviations. $\mathrm{P}=$ Pulleniatina, and $\mathrm{S}=G$. sacculifer. Bin size is $0.2 \%$.

of the five cores (Figs. 4A-4E). For the Brunhes Chron (Cores $130-806 \mathrm{~B}-1 \mathrm{H}$ and $-2 \mathrm{H}$ ), the mean for $\delta^{18} \mathrm{O}$ of $G$. sacculifer is between $-1.30 \%$ and $-1.17 \%$, with a typical range of $1.36 \%$ (taken as four times the standard deviation). The lighter values are the more recent ones. For Pulleniatina, ranges are the same, but values do not become more negative in Core 130-806B-1H. Thus, the oxygen isotope values of the two taxa diverge toward the present. For the next deeper core, which contains the mid-Pleistocene climate shift, this trend continues (i.e., convergence toward the past) and, in addition, ranges diminish. Distributions in Core 130-806B-4H (Fig. 4D) are very similar to those of Core 130-806B-3H (Fig. 4C) except that $G$. sacculifer has now somewhat lighter $\delta^{18} \mathrm{O}$ values. The deepest core of the series has slightly heavier values in both taxa, and a distinctly greater range in Pulleniatina. Separation of means is at a minimum.

In summary, a tendency exists for increased separation of the means of the two planktonic taxa during the Quaternary, and for an increase in the amplitude of fluctuations that is stronger in $G$. sacculifer than in Pulleniatina. The mean $\delta^{18} \mathrm{O}$ value for $G$. sacculifer in the latest Quaternary (Core 130-806B-1H) is the most nega- tive and that of Pulleniatina, the least negative. It is as though the surface water became warmer and the subsurface water colder in the late Quaternary.

In fact, no such inference can be made. Instead, for example, Pulleniatina could be adjusting its depth habitat, making its shell in colder waters in more recent times. G. sacculifer could simply be recording additional melt-water input during interglacials, for instance. A choice between different possibilities of interpreting the trends is not uniquely prescribed by these data.

The basis for all such interpretation are the experiments of Epstein and associates that resulted in the well-known isotopic paleotemperature equation:

$$
t=16.5-4.3\left(\delta_{s}-A\right)+0.14(\delta s-A)_{2},
$$

where $t=$ temperature, $\delta_{s}=$ the $\delta^{18} \mathrm{O}$ value of the solid carbonate, and $A=$ the $\delta^{18} \mathrm{O}$ value of the water in which the carbonate precipitated, measured in the PDB system (Epstein et al., 1953). The $\delta$ value is given as a proportional deviation of isotopic ratios from a standard: $\delta(m)=(R m-R s) / R s$, where $R=$ the ratio of the heavier to the lighter isotope, $m=$ measured, and $s=$ standard. Values for $\delta$ are given in permil, that is, 1000 times the actual value of the deviation.

Term $A$ in Equation 1 is a function mainly of the amount of water locked up in continental ice and the isotopic composition of that ice. Also, it contains information about fractionation processes involving evaporation and precipitation at the sea surface. These processes simultaneously influence salinity, so that an overall correlation exists between salinity and isotopic composition of seawater (Epstein and Mayeda, 1953; Craig and Gordon, 1965). To take account of this correlation, we increase the coefficient of slope in Equation 1 by $10 \%$, so that:

$$
\Delta t=-5 \cdot \Delta \delta_{\text {foram }}
$$

that is, a $1^{\circ} \mathrm{C}$ change in temperature produces a $0.2 \%$ change in the oxygen isotope ratio of foraminiferal tests. In the region studied here, we expect that the temperature range between glacials and interglacials is about the same as the seasonal range, which is near $1^{\circ} \mathrm{C}$ (Reid, 1969). Positive feedback between surface temperature, water vapor, and the greenhouse effect keeps this region at a high temperature, whereas negative cloud feedback keeps the temperature from rising above the value observed $\left(29^{\circ} \mathrm{C}\right)$. In this fashion, we assume, the temperature is stabilized to a narrow range (Ramanathan et al., 1989; Raval and Ramanathan, 1989). Thus, $0.2 \%$ of the $1.36 \%$ range of $G$. sacculifer (late Quaternary; Fig. 4A) may be ascribed to temperature, leaving $1.16 \%$ for the ice effect in the late Quaternary. This estimate agrees well with various previous estimates, which tend to range from $1.1 \%$ to $1.3 \%$ (see Berger and Gardner, 1975; Bender et al., 1985; Chappell and Shackleton, 1986; Fairbanks, 1989). We assume, therefore, that between $85 \%$ and $90 \%$ of the signal of $G$. sacculifer in the late Quaternary marks the ice effect and the rest is caused by temperature changes. Because the amplitude of fluctuations is decreased for the early Quaternary, the proportion of the ice effect should decrease also (unless the temperature range decreases below $1^{\circ} \mathrm{C}$ ).

By coincidence, the local range of $1.3 \%$ in the surface-water foraminifers in the sediments of Ontong Java Plateau corresponds to a global change in sea level during the last $20,000 \mathrm{yr}$ of roughly $130 \mathrm{~m}$, for a ratio of $1 / 100$. Thus, assuming that temperature changes in the surface waters are tied to sea-level changes, and that continental ice does not greatly change its composition through time, the late Quaternary isotopic record on Ontong Java Plateau can be read as a sea-level curve, taking a change of $0.1 \%$ in the $\delta^{18} \mathrm{O}$ as denoting a change in sea level of $10 \mathrm{~m}$ (Shackleton and Opdyke, 1973). The possibility of changing ice composition must be kept in mind when applying this rule of thumb to the more distant past. In addition, vital effects are potentially important (Wefer and Berger, 1991), especially if life histories of the signal carriers change through time. However, 
none of the arguments are affected by "deviation from equilibrium," as commonly defined, unless such deviation changes through time.

\section{Depth Model: Gaps and Patches}

We have noted above (Fig. 2) that the five cores analyzed here are tagged with "correction factors" $(1.0,1.03,1.05,1.04,1.05)$, which derive from the fact that the sediment sections retrieved are longer than those sampled. The reason for the discrepancy is sediment expansion within the core. The factor of 1.05 means that a $9.5-\mathrm{m}$ section expands to fill the barrel. In reality, the expansion factor may be greater, the excess having been lost. Gaps in our isotope record stem from such losses, as well as from sampling gaps across the ends of the cores (usually $20-30 \mathrm{~cm}$, because of failure to sample the very ends).

The section lost, the "coring gap" may be estimated by comparing overlapping records of nearby cores, for example, GRAPE records from Holes $806 \mathrm{~A}, 806 \mathrm{~B}$, and $806 \mathrm{C}$. We made such estimates, but results of this exercise turned out to be unconvincing. As pointed out by Mayer et al. (this volume), the breaks between cores in the three parallel holes (806A, 806B, and 806C) are too close to each other to provide for unambiguous results in detecting gaps. We have used the oxygen isotope record of Hole $805 \mathrm{C}$, therefore, to assess the extent of loss between core breaks (Fig. 5). Fortunately, breaks in Hole 805C are well removed from those in Hole 806B. The resulting conversions from official ODP depths (driller's core top plus distance in core as seen on deck) to something like true depths ("adjusted" meters below seafloor [ambsf]) are as follows (gap at core bottom given in parentheses):

130-806B-1H, 0-6.54 mbsf to 0-6.34 ambsf (gap = 0.16) 130-806B-2H, 6.5-16.34 mbsf to 6.5-15.36 ambsf (gap = 0.74) 130-806B-3H, 16-25.99 mbsf to 16.1-25.19 ambsf (gap = 0.31) $130-806 \mathrm{~B}-4 \mathrm{H}, 25.5-35.42 \mathrm{mbsf}$ to $25.5-34.55 \mathrm{ambsf}$ ( $\mathrm{gap}=0.45$ ) 130-806B-5H, 35-44.98 mbsf to 35-44.08 ambsf

We have, where possible, retained the driller's depths for core tops. Only in one case (130-806B-3H) was it necessary to make a slight adjustment to this rule. Because Mayer et al. (this volume) use composite depths from several holes, our depth assignments are not readily comparable with theirs. The factors that depth-in-core measurements have to be multiplied with to obtain adjusted depths (counting from the fixed core tops) are $0.97,0.9,0.91,0.91$, and 0.91 , respectively, for the five cores. Typically, then, about $3 \%-4 \%$ of the material has been lost from each core.

When comparing the records of Holes $806 \mathrm{~B}$ and $805 \mathrm{C}$, the substantial gap in the crucial interval containing Isotope Stage 19 becomes obvious (Fig. 5). The gap in Stage $9(130-806 \mathrm{~B}-1 \mathrm{H}$ to $-2 \mathrm{H})$ is seen to be of minor importance, and the gap deeper in the record (130$806 \mathrm{~B}-3 \mathrm{H}$ to $-4 \mathrm{H}$ ) is difficult to assess because of the quasi-uniform aspect of the $\delta^{18} \mathrm{O}$ cycles. Either one or two obliquity cycles could be missing. We assume it is one cycle, based on adding coring gap and sampling gap. If Mayer et al. (this volume) are correct about the size of the coring gap (they propose $1 \mathrm{~m}$ ), about two cycles are missing in our record. The obliquity cycle marked 036 then should be 037 . This correction would increase calculated sedimentation rates in Core 130$806 \mathrm{~B}-3 \mathrm{H}$ (see below) by about $10 \%$, but it would not affect other conclusions reached.

We next fill the gaps. The largest and most crucial one at the Brunhes/Matuyama boundary is filled by transplanting the corresponding section from Hole $805 \mathrm{C}$, after expanding it by a factor of 1.2 , to take account of the difference in sedimentation rates (Fig. 6). The gap between Cores $130-806 \mathrm{~B}-1 \mathrm{H}$ and $-2 \mathrm{H}$ is filled by interpolation, with visual guidance from the corresponding portion in Hole $805 \mathrm{C}$ (Fig. 5). The breaks between Cores $130-806 \mathrm{~B}-3 \mathrm{H}$ to $-4 \mathrm{H}$ and between Cores $130-806 \mathrm{~B}-4 \mathrm{H}$ to $-5 \mathrm{H}$ are bridged by shifting the

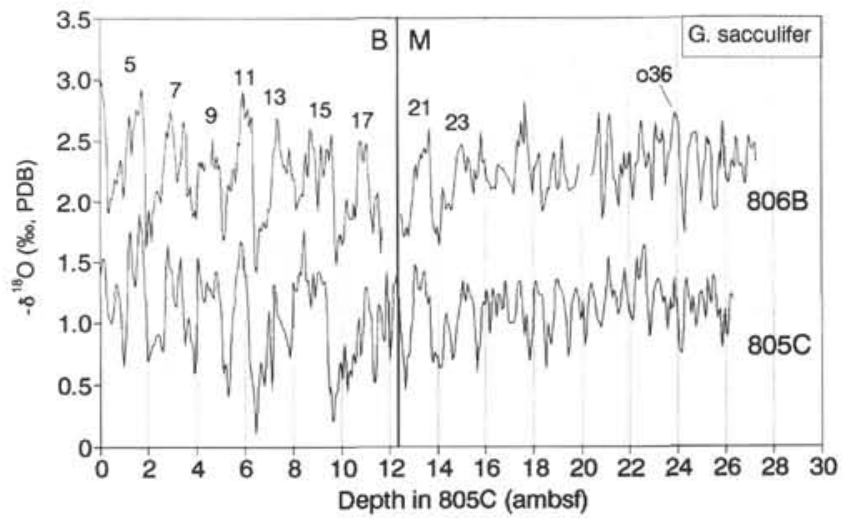

Figure 5. Detailed comparison of oxygen isotope record for G. sacculifer in Hole $806 \mathrm{~B}$ with record in Hole $805 \mathrm{C}$, determined by mapping each core of Hole 806B on the corresponding depth in Hole 805C. Note the gap, in Hole 806B, at the position of Stage 19. Note also the rather poor match in the records below Stage 23. The record of Hole $805 \mathrm{C}$ is from Berger et al. (this volume). The Brunhes/Matuyama (B/M) boundary is as measured on board in Hole $805 \mathrm{C}$ (Kroenke, Berger, Janecek, et al., 1991). ambsf = adjusted meters below seafloor.

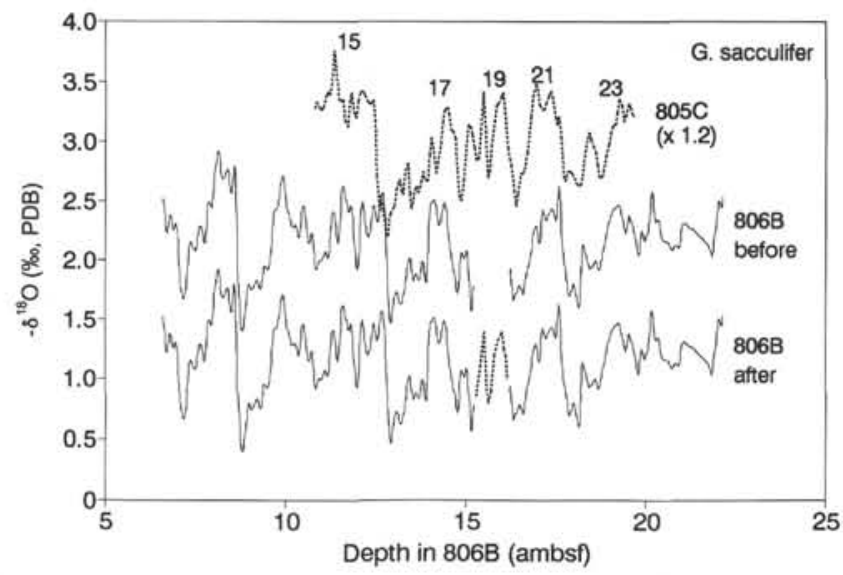

Figure 6. Filling the gap between Cores $130-806 \mathrm{~B}-2 \mathrm{H}$ and $-3 \mathrm{H}$ by transplanting the corresponding section from Hole $805 \mathrm{C}$ (data from Berger et al., this volume). ambsf $=$ adjusted meters below seafloor.

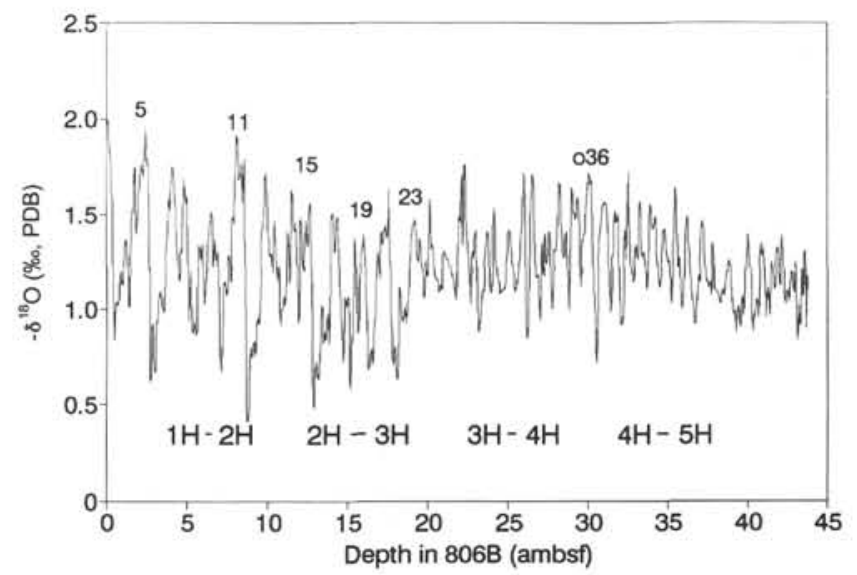

Figure 7. Adjusted depth model of $\delta^{18} \mathrm{O}$ record of $G$. sacculifer for the Quaternary in Hole 806B, based on identification of gaps as shown, and on filling these gaps using comparisons with the corresponding record from Hole $805 \mathrm{C}(1 \mathrm{H}-2 \mathrm{H}$, $2 \mathrm{H}-3 \mathrm{H}$ ), and by shifting autocorrelated sections $(3 \mathrm{H}-4 \mathrm{H}, 4 \mathrm{H}-5 \mathrm{H})$ (see text). 
record downward and upward by one cycle, taking advantage of the high autocorrelation in the early Pleistocene as an aid to interpolation.

The depth model for the Quaternary $\delta^{18} \mathrm{O}$ record of $G$. sacculifer is now complete (Fig. 7). The positions and magnitudes of the gaps that have been filled in the manner described are indicated. Eventually, by comparison with additional $\delta^{18} \mathrm{O}$ records, it will be possible to test for completeness and eliminate idiosyncracies, if necessary. The inferred position of Stage 19 within the gap between Cores 130$806 \mathrm{~B}-2 \mathrm{H}$ and $-3 \mathrm{H}$, and hence the position of the Brunhes/Matuyama boundary within this gap, fully agrees with the detailed biostratigraphic correlations of Takayama (this volume).

\section{Age Model: Counting Obliquity Cycles}

Ever since it was established that orbital frequencies can be recognized in deep-sea records (Hays et al., 1976), the possibility of using these frequencies for dating purposes has been apparent. (The first such attempt, in fact, was made by Emiliani [1955], who claimed that his time scale was locked into a Milankovitch-type irradiation signal.) Dating by "tuning" the time scale for fit to orbital elements can be done in various ways (see Johnson, 1982; Imbrie et al., 1984; Herterich and Sarnthein, 1984; Martinson et al., 1987; Ruddiman et al., 1989; Raymo et al., 1990; Shackleton et al., 1990). Here we use the cyclicity near the period of obliquity (41 k.y.). Our assumption is that the cycles contained in the record, with wavelengths close to $90 \mathrm{~cm}$, represent the effects of obliquity changes on climatic change, and that no change in phase between the orbital forcing function and the climatic response is present. Under this assumption, the number of a cycle dates the sediment. We use the wave-crest number, labeling the youngest crest as zero and setting its age equal to $8 \mathrm{ka}$. The uncertainty of this simple but efficient method is ca. 5 k.y., based on comparison with the high-resolution scales of Martinson et al. (1987) and Imbrie et al. (1984), back to $600 \mathrm{ka}$. Before this time, we estimate the uncertainty as a quarter of the wavelength of the tuning signal, that is, 10 k.y.

To extract the obliquity-related signal, we use the Fourier expansion of the record, after resampling at $2-\mathrm{cm}$ intervals. The Fourier expansion has the form

$$
F(x)=A_{0}+\Sigma[A i \cdot \cos (i x)+B i \cdot \sin (i x)],
$$

where $x$, in this case, $=$ depth or time, and $A_{0}=$ the mean value of $\delta^{18} \mathrm{O}$ in the series. The term $i$ is counted in integer steps and denotes the "order" or "harmonic" of the term in the summation; that is, it represents the number of waves fitted to the length of the series. Terms $A$ and $B$ are the coefficients that are appropriate for each harmonic and that need to be computed. The term $x$ is measured in fractions of $2 \pi$, which is taken to be the length of the record analyzed (or a somewhat longer series, obtained by adding mean values at each end). To synthesize the obliquity-related portion of the record, those terms that are in the vicinity (factor of $<1.2$ ) of the correct wavelength $(80$ $90 \mathrm{~cm}$, from the overall sedimentation rate estimate) are summed. We assume, when doing this, that sedimentation rates vary less than, say, a factor of 1.3 , in any one core, on the scale of 100 k.y.; the fact that the procedure is but moderately sensitive to choice of bandwidth supports the postulate. Note that no further assumptions are made in the analysis beyond the one that the 41-k.y. obliquity cycle should be represented in the isotopic record, as previously demonstrated by time-series analysis (Hays et al., 1976; Morley and Hays, 1981; Pisias and Moore, 1981; Imbrie et al., 1984; Ruddiman et al., 1989).

Results of the procedure yield a template for reading age points along the $\delta^{18} \mathrm{O}$ record. In the corresponding graph (Fig. 8), each 5th obliquity crest is marked (beginning with zero, between 10 and $20 \mathrm{~cm}$ into the core). The marked crests denote time steps of 205 k.y., under the assumption. Note, for example, the obliquity crest number 15 at the shoulder of Isotope Stage 15, where it aids the rapid rise from

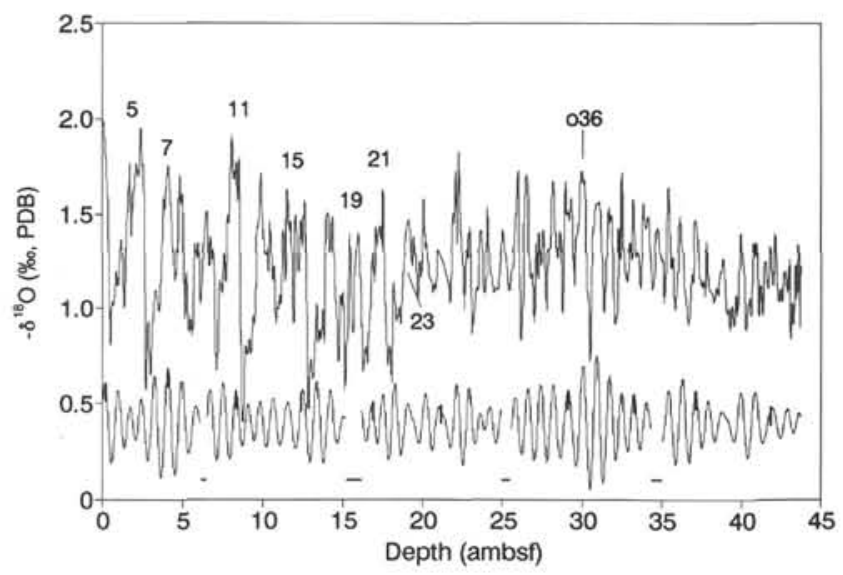

Figure 8. Dating the $\delta^{18} \mathrm{O}$ record of $G$. sacculifer in Hole $806 \mathrm{~B}$ by counting obliquity-related cycles contained in the record. Every 5th crest is marked (darkened peaks), with the difference between crests taken as 41 k.y. The first crest, immediately below seafloor, is counted as zero, and its age is set at $8 \mathrm{ka}$. Isotopic Stage 23 (Shackleton and Opdyke, 1976) is identical to Obliquity Crest 23 (or 023 ). Crest 036 is shown for orientation. ambsf = adjusted meters below seafloor.

Stage 16 (Event 15.5 in Prell et al., 1986). The age of this acme event is given as $617 \mathrm{ka}$ in Imbrie et al. (1984), who used guidance from the Core V28-238 (Shackleton and Opdyke, 1973) and iterative tuning to the Milankovitch record. Obliquity crest number 15 (o15, for short) is here dated at $8+15 \times 41 \mathrm{ka}$ (i.e., $623 \mathrm{ka}$ ). Thus, at least back to this important marker point, our age scale is virtually identical to that of Imbrie et al. (1984).

Discrepancies arise below that level, however. Isotopic Stage 19.1 (for which Imbrie et al. [1984] give an age of $731 \mathrm{ka}$ ) is seen to correspond to o19 in our model. Thus, the age of the main crest is 8 $+19 \times 41 \mathrm{ka}$ (i.e., $787 \mathrm{ka}$ ). The position of the Brunhes/Matuyama boundary is slightly below this level in Holes 805C (Fig. 5; cf. Shackleton and Opdyke, 1973). Thus, our best estimate for the age of this level is $792 \mathrm{ka}$, in good agreement with other recent estimates (Shackleton et al., 1990; Baksi et al., 1992). A slightly younger age emerges, if it is assumed that magnetic reversals are locked into the sediment at some depth below the seafloor (e.g., see deMenocal et al., 1990).

The age model emerging from counting obliquity peaks represents the main result of this study (Fig. 9). The age of the Brunhes/Matuyama boundary is shown as $792 \mathrm{ka}$, and the age of the mid-Pleistocene climate revolution (MPR) as $918 \mathrm{ka}$, at the point where oxygen isotopes first fail to return to previous interglacial values and plunge toward unusually heavy values.

As mentioned, this event is the dominant feature of the Quaternary record. Before this time, the fluctuations are entirely dominated by obliquity. After it, the influence of eccentricity is strong. Taking the record at face value, little or no evidence exists for a transition zone: the change is abrupt-at least on the time scale considered here.

\section{Spectral Properties of the Record}

Spectral analysis of the record shown in Figure 9 (interpolated data in Table 2) reveals strong lines in the vicinity of obliquity and eccentricity, as expected (Fig. 10). The concentration of power at the obliquity position is produced by the method of dating: this is the result of setting the age difference between crests to $41 \mathrm{k} . \mathrm{y}$. The power at 100 k.y. emerges independently; thus, it supports the age scale adopted. Such support, of course, is only valid for that portion of the record where the eccentricity signal is strong (i.e., the late Pleistocene). For the early Pleistocene, the eccentricity component is of negligible importance (Fig. 11). Throughout, signals in the range of 
Table 2. Interpolated negative $\delta^{18} \mathrm{O}$ values for $G$. sacculifer for Cores 130-806B-1H to $-5 \mathrm{H}$ in steps of 4 k.y.

\begin{tabular}{|c|c|c|c|c|c|c|c|c|c|c|c|c|c|}
\hline $\begin{array}{l}\text { Age } \\
\text { (ka) }\end{array}$ & $-\delta^{18} \mathrm{O}$ & $\begin{array}{l}\text { Age } \\
\text { (ka) }\end{array}$ & $-\delta^{18} \mathrm{O}$ & $\begin{array}{l}\text { Age } \\
\text { (ka) }\end{array}$ & $-\delta^{18} \mathrm{O}$ & $\begin{array}{l}\text { Age } \\
\text { (ka) }\end{array}$ & $-\delta^{18} \mathrm{O}$ & $\begin{array}{l}\text { Age } \\
\text { (ka) }\end{array}$ & $-\delta^{18} \mathrm{O}$ & $\begin{array}{l}\text { Age } \\
\text { (ka) }\end{array}$ & $-\delta^{18} \mathrm{O}$ & $\begin{array}{l}\text { Age } \\
\text { (ka) }\end{array}$ & $-\delta^{18} \mathrm{O}$ \\
\hline 0 & 1.98 & 308 & 1.05 & 616 & 1.45 & 924 & 1.01 & 1232 & 1.30 & 1540 & 1.47 & 1848 & 1.15 \\
\hline 4 & 1.99 & 312 & 1.16 & 620 & 1.34 & 928 & 0.94 & 1236 & 1.41 & 1544 & 1.27 & 1852 & 1.33 \\
\hline 8 & 1.91 & 316 & 1.32 & 624 & 1.53 & 932 & 0.99 & 1240 & 1.40 & 1548 & 1.04 & 1856 & 1.47 \\
\hline 12 & 1.75 & 320 & 1.41 & 628 & 1.45 & 936 & 1.11 & 1244 & 1.33 & 1552 & 1.03 & 1860 & 1.43 \\
\hline 16 & 1.61 & 324 & 1.49 & 632 & 0.85 & 940 & 1.24 & 1248 & 1.25 & 1556 & 1.28 & 1864 & 1.33 \\
\hline 20 & 1.31 & 328 & 1.50 & 636 & 0.49 & 944 & 1.35 & 1252 & 1.18 & 1560 & 1.31 & 1868 & 1.17 \\
\hline 24 & 0.86 & 332 & 1.25 & 640 & 0.65 & 948 & 1.43 & 1256 & 1.10 & 1564 & 1.50 & 1872 & 1.15 \\
\hline 28 & 1.00 & 336 & 1.36 & 644 & 0.73 & 952 & 1.46 & 1260 & 1.10 & 1568 & 1.47 & 1876 & 1.12 \\
\hline 32 & 1.03 & 340 & 1.27 & 648 & 0.63 & 956 & 1.44 & 1264 & 1.16 & 1572 & 1.49 & 1880 & 1.14 \\
\hline 36 & 1.04 & 344 & 1.31 & 652 & 0.69 & 960 & 1.30 & 1268 & 1.22 & 1576 & 1.36 & 1884 & 1.10 \\
\hline 40 & 1.15 & 348 & 1.04 & 656 & 0.86 & 964 & 1.32 & 1272 & 1.25 & 1580 & 1.05 & 1888 & 1.19 \\
\hline 44 & 1.18 & 352 & 0.76 & 660 & 1.02 & 968 & 1.31 & 1276 & 1.35 & 1584 & 0.93 & 1892 & 1.35 \\
\hline 48 & 1.13 & 356 & 0.68 & 664 & 0.87 & 972 & 1.17 & 1280 & 1.45 & 1588 & 0.94 & 1896 & 1.13 \\
\hline 52 & 1.19 & 360 & 0.87 & 668 & 0.86 & 976 & 1.14 & 1284 & 1.57 & 1592 & 0.95 & 1900 & 1.10 \\
\hline 56 & 1.29 & 364 & 1.13 & 672 & 0.85 & 980 & 1.20 & 1288 & 1.70 & 1596 & 1.22 & 1904 & 1.09 \\
\hline 60 & 1.36 & 368 & 1.12 & 676 & 0.91 & 984 & 1.24 & 1292 & 1.51 & 1600 & 1.38 & 1908 & 1.08 \\
\hline 64 & 1.24 & 372 & 1.09 & 680 & 0.92 & 988 & 1.53 & 1296 & 0.95 & 1604 & 1.31 & 1912 & 1.05 \\
\hline 68 & 1.01 & 376 & 1.24 & 684 & 0.90 & 992 & 1.33 & 1300 & 0.89 & 1608 & 1.63 & 1916 & 1.04 \\
\hline 72 & 1.09 & 380 & 1.29 & 688 & 1.39 & 996 & 1.33 & 1304 & 1.08 & 1612 & 1.58 & 1920 & 1.10 \\
\hline 76 & 1.32 & 384 & 1.15 & 692 & 1.50 & 1000 & 1.21 & 1308 & 1.35 & 1616 & 1.31 & 1924 & 1.10 \\
\hline 80 & 1.48 & 388 & 1.28 & 696 & 1.47 & 1004 & 1.17 & 1312 & 1.57 & 1620 & 1.22 & 1928 & 1.10 \\
\hline 84 & 1.55 & 392 & 1.49 & 700 & 1.32 & 1008 & 1.16 & 1316 & 1.71 & 1624 & 1.16 & 1932 & 1.19 \\
\hline 88 & 1.74 & 396 & 1.49 & 704 & 1.37 & 1012 & 1.12 & 1320 & 1.62 & 1628 & 1.16 & 1936 & 1.22 \\
\hline 92 & 1.62 & 400 & 1.78 & 708 & 1.48 & 1016 & 1.11 & 1324 & 1.27 & 1632 & 1.25 & 1940 & 1.26 \\
\hline 96 & 1.40 & 404 & 1.92 & 712 & 1.33 & 1020 & 1.12 & 1328 & 1.17 & 1636 & 1.34 & 1944 & 1.15 \\
\hline 100 & 1.55 & 408 & 1.75 & 716 & 1.10 & 1024 & 1.13 & 1332 & 1.19 & 1640 & 1.31 & 1948 & 0.98 \\
\hline 104 & 1.62 & 412 & 1.70 & 720 & 0.97 & 1028 & 1.30 & 1336 & 1.10 & 1644 & 1.31 & 1952 & 0.98 \\
\hline 108 & 1.68 & 416 & 1.76 & 724 & 0.81 & 1032 & 1.31 & 1340 & 0.94 & 1648 & 1.57 & 1956 & 0.92 \\
\hline 112 & 1.76 & 420 & 1.64 & 728 & 0.77 & 1036 & 1.28 & 1344 & 1.23 & 1652 & 1.42 & 1960 & 0.98 \\
\hline 116 & 1.74 & 424 & 1.64 & 732 & 1.06 & 1040 & 1.26 & 1348 & 1.30 & 1656 & 1.28 & 1964 & 0.93 \\
\hline 120 & 1.70 & 428 & 1.68 & 736 & 1.01 & 1044 & 1.22 & 1352 & 1.18 & 1660 & 1.29 & 1968 & 1.04 \\
\hline 124 & 1.79 & 432 & 0.94 & 740 & 1.07 & 1048 & 1.20 & 1356 & 1.36 & 1664 & 1.28 & 1972 & 1.09 \\
\hline 128 & 1.93 & 436 & 0.47 & 744 & 0.93 & 1052 & 1.16 & 1360 & 1.32 & 1668 & 1.19 & 1976 & 1.22 \\
\hline 132 & 1.79 & 440 & 0.43 & 748 & 0.59 & 1056 & 1.11 & 1364 & 1.26 & 1672 & 1.13 & 1980 & 1.38 \\
\hline 136 & 1.72 & 444 & 0.61 & 752 & 0.80 & 1060 & 1.12 & 1368 & 1.37 & 1676 & 1.31 & 1984 & 1.24 \\
\hline 140 & 1.25 & 448 & 0.79 & 756 & 0.88 & 1064 & 1.42 & 1372 & 1.40 & 1680 & 1.52 & 1988 & 1.17 \\
\hline 144 & 0.63 & 452 & 0.76 & 760 & 1.07 & 1068 & 1.46 & 1376 & 1.18 & 1684 & 1.50 & 1992 & 0.91 \\
\hline 148 & 0.84 & 456 & 0.77 & 764 & 1.36 & 1072 & 1.67 & 1380 & 1.00 & 1688 & 1.44 & 1996 & 0.94 \\
\hline 152 & 0.92 & 460 & 0.83 & 768 & 1.11 & 1076 & 1.36 & 1384 & 1.15 & 1692 & 1.42 & 2000 & 1.01 \\
\hline 156 & 0.74 & 464 & 0.79 & 772 & 0.88 & 1080 & 1.75 & 1388 & 1.32 & 1696 & 1.47 & 2004 & 1.05 \\
\hline 160 & 0.71 & 468 & 0.79 & 776 & 1.00 & 1084 & 1.58 & 1392 & 1.32 & 1700 & 1.48 & 2008 & 0.97 \\
\hline 164 & 0.92 & 472 & 0.93 & 780 & 1.21 & 1088 & 1.38 & 1396 & 1.43 & 1704 & 1.32 & 2012 & 1.19 \\
\hline 168 & 1.00 & 476 & 0.94 & 784 & 1.31 & 1092 & 1.26 & 1400 & 1.63 & 1708 & 1.20 & 2016 & 1.34 \\
\hline 172 & 1.08 & 480 & 0.95 & 788 & 1.38 & 1096 & 1.13 & 1404 & 1.62 & 1712 & 1.11 & 2020 & 1.29 \\
\hline 176 & 1.10 & 484 & 1.13 & 792 & 1.28 & 1100 & 1.10 & 1408 & 1.43 & 1716 & 1.15 & 2024 & 1.31 \\
\hline 180 & 1.05 & 488 & 1.39 & 796 & 1.04 & 1104 & 1.30 & 1412 & 1.33 & 1720 & 1.20 & 2028 & 0.98 \\
\hline 184 & 1.00 & 492 & 1.44 & 800 & 0.79 & 1108 & 1.28 & 1416 & 1.28 & 1724 & 1.30 & 2032 & 1.11 \\
\hline 188 & 1.04 & 496 & 1.54 & 804 & 0.70 & 1112 & 1.34 & 1420 & 1.40 & 1728 & 1.40 & 2036 & 1.04 \\
\hline 192 & 1.23 & 500 & 1.70 & 808 & 0.76 & 1116 & 1.41 & 1424 & 1.29 & 1732 & 1.42 & 2040 & 1.13 \\
\hline 196 & 1.37 & 504 & 1.63 & 812 & 0.75 & 1120 & 1.32 & 1428 & 1.00 & 1736 & 1.39 & 2044 & 1.23 \\
\hline 200 & 1.55 & 508 & 1.42 & 816 & 0.78 & 1124 & 0.94 & 1432 & 1.26 & 1740 & 1.30 & 2048 & 1.13 \\
\hline 204 & 1.54 & 512 & 1.34 & 820 & 0.93 & 1128 & 0.90 & 1436 & 1.64 & 1744 & 1.26 & 2052 & 1.16 \\
\hline 208 & 1.65 & 516 & 1.28 & 824 & 1.01 & 1132 & 0.97 & 1440 & 1.53 & 1748 & 1.25 & 2056 & 1.33 \\
\hline 212 & 1.75 & 520 & 1.29 & 828 & 1.21 & 1136 & 1.02 & 1444 & 1.51 & 1752 & 1.26 & 2060 & 1.18 \\
\hline 216 & 1.69 & 524 & 1.21 & 832 & 1.29 & 1140 & 1.10 & 1448 & 1.48 & 1756 & 1.07 & 2064 & 1.21 \\
\hline 220 & 1.59 & 528 & 1.42 & 836 & 1.21 & 1144 & 1.10 & 1452 & 1.58 & 1760 & 1.10 & 2068 & 1.38 \\
\hline 224 & 1.46 & 532 & 1.38 & 840 & 1.23 & 1148 & 1.15 & 1456 & 1.45 & 1764 & 1.23 & 2072 & 1.20 \\
\hline 228 & 1.27 & 536 & 1.18 & 844 & 1.41 & 1152 & 1.27 & 1460 & 1.14 & 1768 & 1.41 & 2076 & 1.05 \\
\hline 232 & 1.16 & 540 & 1.21 & 848 & 1.35 & 1156 & 1.39 & 1464 & 1.33 & 1772 & 1.62 & 2080 & 1.07 \\
\hline 236 & 1.22 & 544 & 1.04 & 852 & 1.38 & 1160 & 1.41 & 1468 & 1.39 & 1776 & 1.50 & 2084 & 1.08 \\
\hline 240 & 1.31 & 548 & 0.96 & 856 & 1.42 & 1164 & 1.36 & 1472 & 1.41 & 1780 & 1.27 & 2088 & 1.07 \\
\hline 244 & 1.43 & 552 & 1.00 & 860 & 1.43 & 1168 & 1.17 & 1476 & 1.55 & 1784 & 1.26 & 2092 & 1.18 \\
\hline 248 & 1.68 & 556 & 1.05 & 864 & 1.39 & 1172 & 1.09 & 1480 & 1.70 & 1788 & 1.14 & 2096 & 1.19 \\
\hline 252 & 1.58 & 560 & 1.03 & 868 & 1.53 & 1176 & 1.11 & 1484 & 1.71 & 1792 & 1.00 & 2100 & 1.13 \\
\hline 256 & 1.57 & 564 & 1.26 & 872 & 1.44 & 1180 & 1.18 & 1488 & 1.66 & 1796 & 1.08 & 2104 & 1.10 \\
\hline 260 & 1.09 & 568 & 1.39 & 876 & 1.06 & 1184 & 1.41 & 1492 & 1.60 & 1800 & 1.17 & 2108 & 1.25 \\
\hline 264 & 1.06 & 572 & 1.18 & 880 & 0.90 & 1188 & 1.47 & 1496 & 1.15 & 1804 & 1.33 & 2112 & 0.97 \\
\hline 268 & 1.15 & 576 & 1.54 & 884 & 0.75 & 1192 & 1.27 & 1500 & 1.05 & 1808 & 1.48 & 2116 & 0.93 \\
\hline 272 & 0.93 & 580 & 1.58 & 888 & 0.74 & 1196 & 1.21 & 1504 & 0.77 & 1812 & 1.37 & 2120 & 0.97 \\
\hline 276 & 0.89 & 584 & 1.42 & 892 & 0.80 & 1200 & 1.17 & 1508 & 0.88 & 1816 & 1.30 & 2124 & 0.99 \\
\hline 280 & 0.92 & 588 & 1.45 & 896 & 0.70 & 1204 & 1.14 & 1512 & 1.26 & 1820 & 1.13 & 2128 & 1.21 \\
\hline 284 & 0.88 & 592 & 1.10 & 900 & 0.64 & 1208 & 1.09 & 1516 & 1.42 & 1824 & 1.06 & 2132 & 1.08 \\
\hline 288 & 1.15 & 596 & 0.96 & 904 & 1.05 & 1212 & 1.10 & 1520 & 1.45 & 1828 & 0.99 & 2136 & 1.27 \\
\hline 292 & 1.33 & 600 & 1.47 & 908 & 1.08 & 1216 & 1.11 & 1524 & 1.52 & 1832 & 0.93 & 2140 & 1.18 \\
\hline 296 & 1.29 & 604 & 1.33 & 912 & 0.99 & 1220 & 1.11 & 1528 & 1.56 & 1836 & 0.95 & & \\
\hline 300 & 1.32 & 608 & 1.20 & 916 & 0.94 & 1224 & 1.13 & 1532 & 1.55 & 1840 & 1.07 & & \\
\hline 304 & 1.23 & 612 & 1.35 & 920 & 0.96 & 1228 & 1.21 & 1536 & 1.56 & 1844 & 1.17 & & \\
\hline
\end{tabular}

Note: Gaps at core breaks are identified and filled as described in text. 


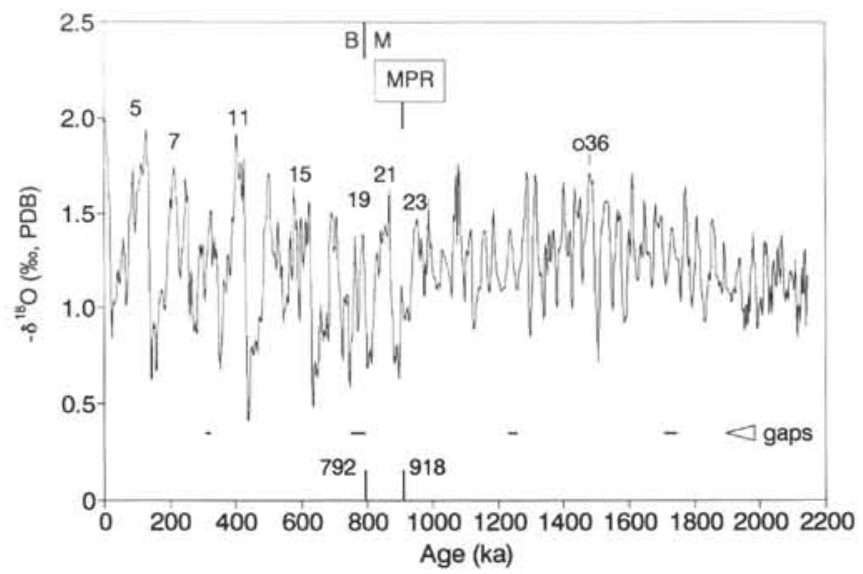

Figure 9. Age model of the $\delta^{18} \mathrm{O}$ record of G. sacculifer in Hole 806B on the Ontong Java Plateau. $\mathrm{B} / \mathrm{M}=$ Brunhes/Matuyama boundary, and $\mathrm{MPR}=$ mid-Pleistocene climate revolution, switching the nature of climatic cycles from obliquity-dominated to mixed cycles (eccentricity and obliquity). The ages of the two events are given at the bottom of the graph.

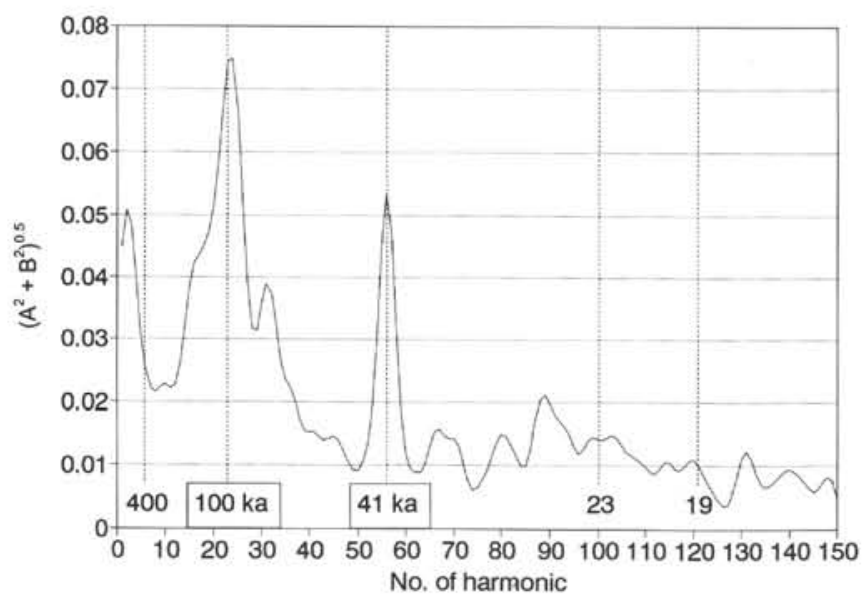

Figure 10. Magnitude of Fourier coefficients of the $\delta^{18} \mathrm{O}$ of $G$. sacculifer in Quaternary sediments of Hole 806B, Ontong Java Plateau. The record shown in Figure 9 was extended at the ends to 2300 k.y. (using the autocorrelation properties of the record), tapered and expressed in terms of Fourier expansion (Eq. 3). Magnitude is given as the square root of the sum of squares.

precession (23 and 19 k.y.) appear to be in the noise range, although there is some slight power above background near 25 k.y. (Fig. 10).

For the late Pleistocene, the amplitude of the eccentricity-related contribution is seen to be substantially greater than the obliquity-related contribution to the record (Fig. 11). For the early Pleistocene the reverse is the case.

How sensitive are these amplitudes to the choice of bandwidth in synthesizing selected portions of the record? This question is explored by changing the number of harmonics admitted at either side of the pure orbital tone. For eccentricity, results show that the amplitude is not very sensitive to bandwidth (Fig. 12); that is, the stratigraphy of amplitudes in the eccentricity band remains much the same when widening the window, once it includes a factor of 1.1 on either side.

\section{On the Nature of the mid-Pleistocene Climate Revolution}

Inspection of the record (Fig. 9) reveals that two regimes of cyclicity are present: an older one dominated by obliquity, and a

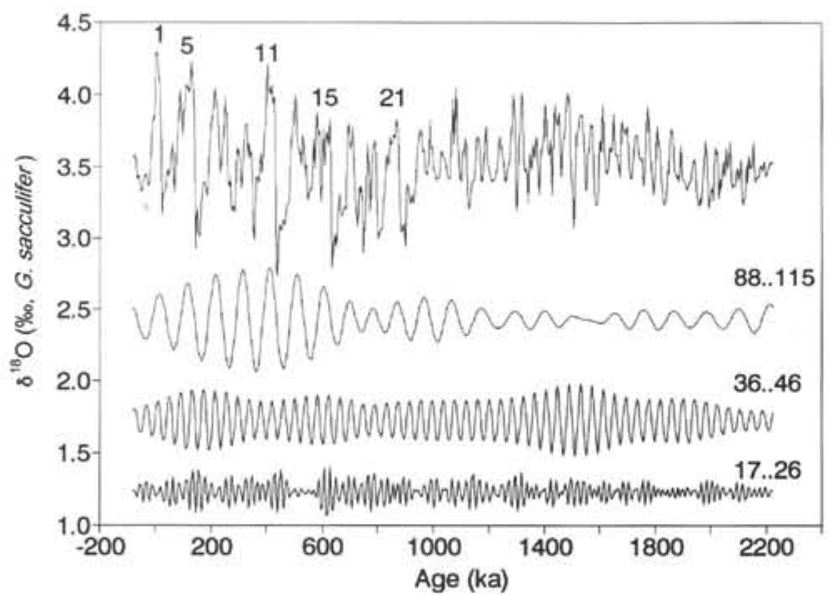

Figure 11. Amplitudes of the orbit-related fluctuations within the $\delta^{18} \mathrm{O}$ record of G. sacculifer, Hole 806B (extended), Ontong Java Plateau. Top curve: record as given in Figure 9; next curve down: eccentricity-related fluctuations (harmonics for periods between 88 and 115 k.y.); next curve down: obliquity-related fluctuations (harmonics for periods between 36 and 46 k.y.); and bottom curve: precession-related fluctuations (harmonics for periods between 17 and 26 k.y.).

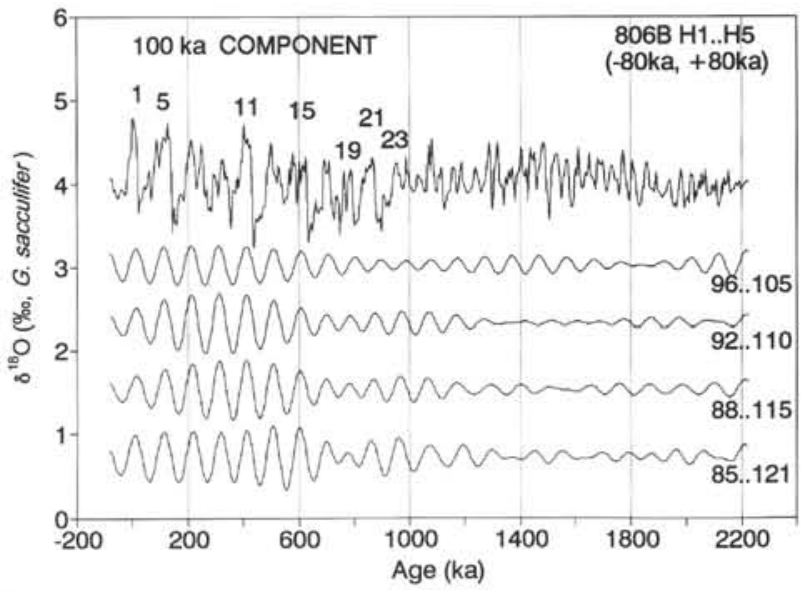

Figure 12. Sensitivity of eccentricity-related amplitude to bandwidth chosen for synthesis from Fourier coefficients. Curve labeled " $96 . .105$ " represents bandwidth from 96 to 105 k.y., curve labeled " $92 . .110$ " represents bandwidth from 92 to 110 k.y., and so forth. Amplitudes change little on widening the window (see text).

younger one that shows a strong response to eccentricity-related forcing. This observation is supported by spectral analysis. The presence of a profound change of the climatic system at about $1 \mathrm{Ma}$ has been well appreciated for some time (e.g., Pisias and Moore, 1981; Pestiaux and Berger, 1984; Ruddiman et al., 1986, 1989; Ruddiman and Raymo, 1988; Shackleton et al., 1988; Hagelberg et al., 1991).

The reason why the $\delta^{18} \mathrm{O}$ record of foraminifers (planktonic and benthic) shows the shift in response to orbital forcing near $900 \mathrm{ka}$ is obscure. The carbonate record of the central equatorial Pacific suggests that changes in the intensity of North Atlantic Deep Water (NADW) production were involved (Farrell and Prell, 1991), with the system being much more sensitive to precessional forcing after $900 \mathrm{ka}$. However, this change in sensitivity may be a consequence rather than a cause of the overall climate shift. For the modification of long-term response, in principle, crustal motion is a prime candidate (Emiliani and Geiss, 1958), as well as deep shelf erosion. Uplift 


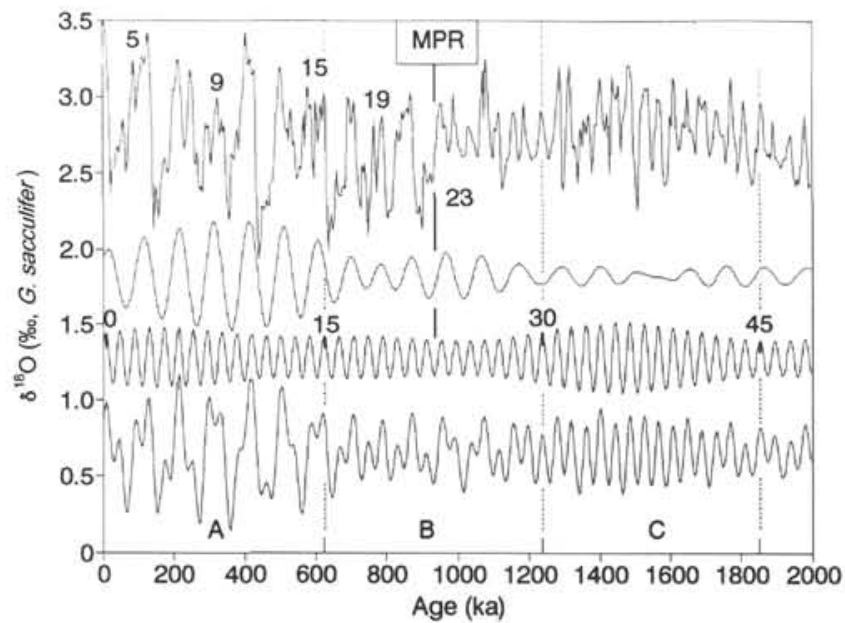

Figure 13. The Quaternary $\delta^{18} \mathrm{O}$ record of $G$. sacculifer in Hole 806B compared with its major components, those related to the eccentricity of the Earth's orbit (ca. 100 k.y.) and the obliquity of its axis (ca. 41 k.y.). The curve at the bottom is the sum of the two in the middle; it captures the main features of the record. $\mathrm{MPR}=$ mid-Pleistocene climate revolution .

of highlands (and associated albedo-related thresholds), and an increase of marine-based ice sheets (to increase instability) are attractive propositions (see Ruddiman and Raymo, 1988, for a recent review). Questions regarding the response of the system to forcing require a broad-front attack using many different signals from various environments (e.g., Imbrie et al., 1989). Here we ask a rather simple question: Is the mid-Pleistocene climate revolution a result of gradual change or is it abrupt?

Abruptness is a matter of definition and the time scale considered (Berger and Labeyrie, 1987). A useful way to pursue the question, therefore, is to concentrate on the residual record that remains after subtracting the orbit-related fluctuations from the record (Imbrie, 1987). Is a specific event indicated that clearly deviates from the trends prescribed by long-term fluctuations?

We first turn to eccentricity-and obliquity-related fluctuations, the ones that dominate the record. Combining these portions of the spectrum, we find that the major features of the record are well depicted (Fig. 13, lowermost curve). However, no indication is present of an abrupt change near $900 \mathrm{ka}$, as identified in Figure 9. Instead, there is an indication of three sections: one where the eccentricity-related signal is dominant $(\mathrm{A})$, one where obliquity reigns $(\mathrm{C})$, and one where there is a roughly equal mixture of both (B). These subdivisions (A, B, and C) correspond to the sections labeled "Milankovitch," "Croll," and "Laplace" in Berger and Wefer (in press). The boundaries are defined (arbitrarily) as the crests of obliquity cycles 15, 30, and 45. The nature of the synthetic record at the bottom suggests that a change in a linear response to eccentricity and obliquity cannot, by itself, explain the mid-Pleistocene climate shift.

The shift (or something like it) does appear when we consider the first 25 harmonics (periods from eccentricity upward; i.e., $>92 \mathrm{ka}$ ), and also when we synthesize a curve from the main 13 harmonics (including obliquity) (see Fig. 14). Subtracting either of these synthetic records from the original, we find that no special residual is present in the vicinity of $900 \mathrm{ka}$, that is, the mid-Pleistocene climate shift. Thus, the long periods contained in the record are sufficient to "explain" the shift, and no special incident need be called upon.

As concerns the curves representing the residuals after removal of long periods or main periods (Fig. 14), it is interesting that unusual amplitudes are preferentially found in the late Pleistocene rather than in the early part. The extreme amplitude of Stage 12 stands out especially. Somewhat erratic precessional signals may be responsible, or instabilities in phase in the response to eccentricity-related forcing.

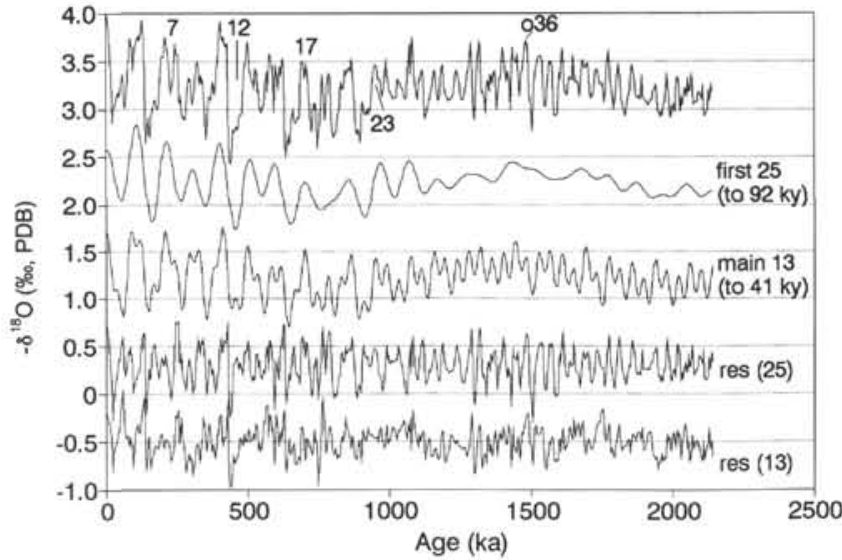

Figure 14. Residuals of the Quaternary $\delta^{18} \mathrm{O}$ record of $G$. sacculifer in Hole $806 \mathrm{~B}$ after subtracting long-period fluctuations ("first 25 " harmonics, down to $92 \mathrm{ka}$ ) and after subtracting the 13 dominant harmonics (which includes obliquity at $41 \mathrm{ka}$ ). Residuals are marked "res(25)" and "res(13)," accordingly. No evidence is present for a special amplitude of residuals near $900 \mathrm{ka}$ (mid-Pleistocene climate revolution).

Does the absence of evidence for residuals preclude the existence of a distinct identifiable boundary? Probably not. The change in spectrum is rather distinct. The gradual development of the eccentricity response that appears when analyzing long sections (as in Fig. 13) may be misleading. When arbitrarily defined sections are analyzed, naturally a mixture of spectral information is present in the section that overlaps the major climatic regimes (compare Figs. 15A and 15C with Figs. 15B and 15D). When the sections above and below the mid-Pleistocene climate shift are analyzed separately, however, their fundamental difference becomes very clear (Figs. 15E-15F).

What similarity that does exist between the "pre-MPR" and "postMPR" sections derives from the fact that obliquity-related fluctuations persist into the late Quaternary. The influence of eccentricity is practically zero in the early Quaternary in this $\delta^{18} \mathrm{O}$ record. The marked split in the eccentricity-related component in Section B is noteworthy. This apparently stems from a phase adjustment (see Fig. 14, "first 25," at Stage 19). The need for this adjustment would disappear were we to assign an age of $820 \mathrm{ka}$ to Peak 19.1 (the older peak of Stage 19). However, Stage 19 does not seem long enough to be able to accommodate two obliquity peaks. The weakness or absence of precession-related signal is remarkable. Perhaps strong fluctuations of sedimentation rate, at these frequencies, interfere with the recording of such a signal.

\section{Sedimentation Rates}

Our age assignments, based on counting obliquity-related cycles in the record, allow the recovery of "instant" sedimentation rates (ISR) on the scale of eccentricity and longer (Fig. 16). The average of these rates is as expected from the biostratigraphy present in the cores recovered (see Takayama, this volume). Also, a slight tendency toward higher rates exists toward the bottom of the section studied in the latest Pliocene. The record of ISR shows long-term fluctuations with a typical amplitude of $20 \%$ on either side of the mean.

There is a hint of a period near $400 \mathrm{k} . \mathrm{y}$., which may correspond to a beat in the amplitude of eccentricity. Unfortunately, the section within each core barrel $(9.5 \mathrm{~m}$ at $20 \mathrm{~m} / \mathrm{m} . \mathrm{y}$.) is of the same order as the beat observed, so that it is not clear to us whether this apparent fluctuation might not result, at least in part, from artifacts introduced when bridging the gap across cores. The ISR values are rather sensitive to small errors in estimating gap size. At least two of the minima in ISR shown coincide with gaps (Fig. 16). 
In support of a circa- $400 \mathrm{k} . \mathrm{y}$. beat, we should mention that carbonate cycles with this approximate period have been identified in deep-sea sediments from the central Pacific (e.g., van Andel et al., 1975). On land, the loess stratigraphy in China appears to show cycles of about this magnitude (see Fig. 19 in Kukla, 1987), suggesting an influence of long-period changes in wind regime. Visual comparison of the ISR record (Fig. 16) with the eccentricity of Earth's orbit (Berger, 1978, 1984) suggests that intervals containing large eccentricity excursions coincide with higher rates of sedimentation.

The processes influencing the ISR record have to do with the available supply of carbonate (as the sediment is $90 \%$ carbonate), and with preservation and winnowing. It will be of interest to investigate whether productivity-related signals (carbon isotopes in planktonic and benthic foraminifers, abundance of benthic foraminifers, possibly diatomaceous deposits) have a strong 400-k.y. periodicity. In any case, no obvious correlation exists with the records for sand and carbonate (Fig. 17). For winnowing effects to be important, a negative correlation would be expected with sand (which is seen in places). A case can be made, perhaps, that the maximum carbonate values near $1 \mathrm{Ma}$ coincide with maximum sedimentation rates. Also, some indication is present that relative warmer periods tend to have higher rates of sedimentation, at least in pre-MPR time (Fig. 17, comparison with $\delta^{18} \mathrm{O}$ record).

\section{CONCLUSIONS}

Our main goal here was to present, in some detail, an oxygen isotope record that could serve as a standard for Quaternary chronology, to complement the records from nearby Cores V28-238 and V28-239 published by Shackleton and Opdyke $(1973,1976)$. We have attempted to show that the record of Hole 806B is excellent, except for core breaks. The main coring-gap problem exists at Isotopic Stage 19, which contains the Brunhes/Matuyama boundary. By importing the corresponding record from Hole $805 \mathrm{C}$, we were able to bridge this gap. By counting the cycles related to obliquity, within the $\delta^{18} \mathrm{O}$ record, we constructed an age scale independent of biostratigraphy (except for general guidance as to the overall sedimentation rate) and of various other proposed scales (Table 3 and Fig. 18).

We date the Brunhes/Matuyama boundary at $792 \mathrm{ka}( \pm 10 \mathrm{k.y}$.), in excellent agreement with previous estimates based on tuning to astronomical signals (Johnson, 1982, $790 \pm 5 \mathrm{ka}$; Shackleton et al., 1990 , ca. $780 \mathrm{ka}$ ), and with recent radiometric determinations (Izett and Obradovich, 1991; Baksi et al., 1992). Thus, we are fairly confident that the conventional age of $730 \mathrm{ka}$ for this boundary must be abandoned.

The rather abrupt appearance of a strong response of the oceanclimate system to eccentricity-related forcing emerges as the major feature of the Quaternary record of the Ontong Java Plateau (as elsewhere; Pisias and Moore, 1981; Ruddiman et al., 1986). We date the break at $918 \mathrm{ka}$. We find that it is not necessary to call for a sudden event at the position of the main change; instead, superposition of long cycles is sufficient cause. Two questions arise: why does a response to eccentricity occur at all, as the changes in irradiation are so small; and why does this response make its appearance about $0.9 \mathrm{Ma}$. There does not appear to be any reason to suspect a pronounced change in orbital characteristics at that time (Berger, 1984). A number of suggestions have been put forward to explain the onset of a strong 100-ka climatic cycle in the late Quaternary (see Pisias and Moore, 1981; Imbrie, 1985; Ruddiman et al., 1986). The proposal that long-term changes in elevation caused by ice loading and unloading are involved (Emiliani and Geiss, 1958) remains attractive, which would suggest that the effects of ice erosion on continental margins in high latitudes and an increasing transient ice mass (i.e., amplitude of sea-level change) provide the key to the change in boundary conditions $0.9 \mathrm{Ma}$.

Interestingly, the change in response of the system to astronomic forcing is not accompanied by obvious changes in the trends of sedi- mentation rates. Instead, a quasi-400 k.y. cycle (460 k.y. in the spectrum) appears to dominate. Unfortunately, interference from core breaks may be present. Sand content increases and carbonate decreases, on the whole, after the mid-Pleistocene climate shift (Fig. 17). We suggest that this is the result of increased winnowing during glacial periods. The weakness of precession-related signals in our record is noteworthy.

\section{ACKNOWLEDGMENTS}

We thank the members of the shipboard party of Leg 130 for assistance in sampling and other help rendered during the cruise. Dr. M. Segl, Bremen, supervised and facilitated the generation of the isotope data. Tom Janecek provided the carbonate data used in Figure 17, as well as the GRAPE data used for checking on core breaks. We are indebted to two critical reviewers for helpful suggestions.

\section{REFERENCES*}

Baksi, A.K., Hsu, V., McWilliams, M.O., and Farrar, E., $1992 .{ }^{40} \mathrm{Ar} /{ }^{39}$ Ar dating of the Brunhes-Matuyama geomagnetic field reversal. Science, 256:356-357.

Bender, M., Labeyrie, L.D., Raynaud, D., and Lorius, C., 1985. Isotopic composition of atmospheric $\mathrm{O}_{2}$ in ice linked with deglaciation and global primary productivity. Nature, 318:349-352.

Berger, A., 1984. Accuracy and frequency stability of the Earth's orbital elements during the Quaternary. In Berger, A., Imbrie, J., Hays, J., Kukla, G., and Saltzman, B. (Eds.), Milankovitch and Climate (Pt. 1): Dordrecht (D. Reidel), 3-39.

Berger, A.L., 1978. Long-term variations of caloric inisolation resulting from the Earth's orbital elements. Quat. Res., 9:139-167.

Berger, W.H., Bonneau, M.-C., and Parker, F.L., 1982. Foraminifera on the deep-sea floor: lysocline and dissolution rate. Oceanol. Acta, 5:249-258.

Berger, W.H., and Gardner, J.V., 1975. On the determination of Pleistocene temperatures from planktonic foraminifera. J. Foraminiferal Res., 5:102-113.

Berger, W.H., Killingley, J.S., and Vincent, E., 1978. Stable isotopes in deep-sea carbonates: Box Core ERDC-92, west equatorial Pacific. Oceanol. Acta, 1:203-216.

Berger, W.H., Kroenke, L.W., Mayer, L.A., and Shipboard Scientific Party, 1991. Ontong Java Plateau, Leg 130: synopsis of major drilling results. In Kroenke, L.W., Berger, W.H., Janecek, T.R., et al., Proc. ODP, Init. Repts., 130: College Station, TX (Ocean Drilling Program), 497-537.

Berger, W.H., and Labeyrie, L.D., 1987. Abrupt climatic change - an introduction. In Berger, W.H., and Labeyrie, L.D. (Eds.), Abrupt Climatic Change-Evidence and Implications: Dordrecht (D. Reidel), 3-14.

Berger, W.H., and Wefer, G., in press. Klimageschichte aus TiefseesedimentenNeues vom Ontong Java Plateau (Westpazifik). Naturwissenschaften.

Chappell, J., and Shackleton, N.J., 1986. Oxygen isotopes and sea level. Nature, 324:137-140.

Craig, H., and Gordon, L.I., 1965. Deuterium and oxygen 18 variations in the ocean and the marine atmosphere. In Tongiorgi, E. (Ed.), Stable Isotopes in Oceanographic Studies and Paleotemperatures: Pisa (Cons. Naz. delle Ric., Lab. di Geol. Nucleare), 9-130.

DeMenocal, P.B., Ruddiman, W.F., and Kent, D.V., 1990. Depth of post-depositional remanence acquisition in deep-sea sediments: a case study of the Brunhes-Matuyama reversal and oxygen isotopic Stage 19.1. Earth Planet. Sci. Lett., 99:1-13.

Emiliani, C., 1955. Pleistocene temperatures. J. Geol., 63:538-578.

Emiliani, C., and Geiss, J., 1958. On glaciation and their causes. Geol. Rundsch., 46:576-601.

Epstein, S., Buchsbaum, R., Lowenstam, H.A., and Urey, H.C., 1953. Revised carbonate-water isotopic scale. Geol. Soc. Am. Bull., 64:1315-1325.

Epstein, S., and Mayeda, T., 1953. Variation of ${ }^{18} \mathrm{O}$ content of waters from natural sources. Geochim. Cosmochim. Acta, 4:213-224.

Fairbanks, R.G., 1989. A 17,000-year glacio-eustatic sea level record: influence of glacial melting rates on the Younger Dryas event and deep-ocean circulation. Nature, 342:637-642.

\footnotetext{
* Abbreviations for names of organizations and publication titles in ODP reference lists follow the style given in Chemical Abstracts Service Source Index (published by American Chemical Society).
} 
Farrell, J.W., and Prell, W.L., 1991.Pacific $\mathrm{CaCO}_{3}$ preservation and $\delta^{18} \mathrm{O}$ since 4 Ma: paleoceanic and paleoclimatic implications. Paleoceanography, 6:485-498.

Grötsch, J., Wu, G., and Berger, W.H., 1991. Carbonate cycles in the Pacific: reconstruction of saturation fluctuations. In Einsele, G., Ricken, W., and Seilacher, A. (Eds.), Cycles and Events in Stratigraphy: Heidelberg (Springer-Verlag), 110-125.

Hagelberg, T., Pisias, N., and Elgar, S., 1991. Linear and nonlinear couplings between orbital forcing and the marine $\delta^{18} \mathrm{O}$ record during the late Neogene. Paleoceanography, 6:729-746.

Hays, J.D., Imbrie, J., and Shackleton, N.J., 1976. Variations in the earth's orbit: pacemaker of the ice ages. Science, 194:1121-1132.

Hebbeln, D., Wefer, G., and Berger, W.H., 1990. Pleistocene dissolution fluctuations from apparent depth of deposition in Core ERDC-127P, westequatorial Pacific. Mar. Geol., 92:165-176.

Herterich, K., and Sarnthein, M., 1984. Brunhes time scale: tuning by rates of calcium-carbonate dissolution and cross spectral analyses with solar insolation. In Berger, A., Imbrie, J., Hays, J., Kukla, G., and Saltzman, B. (Eds.), Milankovitch and Climate (Pt. 1): Dordrecht (D. Reidel), 447-466.

Imbrie, J., 1985. A theoretical framework for the Pleistocene ice ages. J. Geol. Soc. London, 142:417-432.

, 1987. Abrupt terminations of late Pleistocene ice ages: a simple Milankovitch explanation. In Berger, W.H., and Labeyrie, L.D. (Eds.), Abrupt Climatic Change-Evidence and Implications: Dordrecht (D. Reidel), 365-367.

Imbrie, J., Hays, J.D., Martinson, D.G., McIntyre, A., Mix, A.C., Morley, J.J., Pisias, N.G., Prell, W.L., and Shackleton, N.J., 1984. The orbital theory of Pleistocene climate: support from a revised chronology of the marine delta $\delta^{18} \mathrm{O}$ record. In Berger, A., Imbrie, J., Hays, J., Kukla, G., and Saltzman, B. (Eds.), Milankovitch and Climate (Pt. 1): Dordrecht (D. Reidel), 269-305.

Imbrie, J., McIntyre, A., and Mix, A., 1989. Oceanic response to orbital forcing in the late Quaternary: observational and experimental strategies. In Berger, A., Schneider, S., and Duplessy, J.C. (Eds.), Climate and Geo-Sciences: Dordrecht (Kluwer Academic), 121-164.

Izett, G., and Obradovich, J., 1991. Dating of the Matuyama-Brunhes boundary based on ${ }^{40} \mathrm{Ar}{ }^{39} \mathrm{Ar}$ ages of the Bishop Tuff and Cerro San Luis rhyolite. Geol. Soc. Am. Abstr. Programs, 23:A106.

Izett, G., Obradovich, J.D., and Mehnert, H.H., 1988. The Bishop ash bed (middle Pleistocene) and some older (Pliocene and Pleistocene) chemically and mineralogically similar ash beds in California, Nevada, and Utah. U.S. Geol. Surv. Bull., 1675:1-37.

Johnson, R.G., 1982. Brunhes-Matuyama magnetic reversal dated at 790,000 yr B.P. by marine-astronomical correlations. Quat. Res., 17:135-147.

Kroenke, L.W., Berger, W.H., Janecek, T.R., et al., 1991. Proc. ODP, Init. Repts., 130: College Station, TX (Ocean Drilling Program).

Kukla, G., 1987. Loess stratigraphy in central China. Quat. Sci. Rev., 6:191-219.

Le, J., and Shackleton, N.J., 1992. Carbonate dissolution fluctuations in the western equatorial Pacific during the late Quaternary. Paleoceanography, 7:21-42.

Martinson, D.G., Pisias, N.G., Hays, J.D., Imbrie, I., Moore, T.C., Jr., and Shackleton, N.J., 1987. Age dating and the orbital theory of the ice-ages: development of a high-resolution 0 to 300,000 -year chronostratigraphy. Quat. Res. NY, 27:1-29.

Morley, J.J., and Hays, J.D., 1981. Towards a high-resolution, global, deep-sea chronology for the last 750,000 years. Earth Planet. Sci. Lett., 53:279-295.

Pestiaux, P., and Berger, A., 1984. An optimal approach to the spectral characteristics of deep-sea climatic records. In Berger, A., Imbrie, J., Hays, J., Kukla, G., and Saltzman, B. (Eds.), Milankovitch and Climate (Pt. 1): Dordrecht (D. Reidel), 417-445.

Pisias, N.G., and Moore, T.C., Jr., 1981. The evolution of Pleistocene climate: a time series approach. Earth Planet. Sci. Lett., 52:450-456.
Prell, W.L., Imbrie, J., Martinson, D.G., Morley, J.J., Pisias, N.G., Shackleton, N.J., and Streeter, H.F., 1986. Graphic correlation of oxygen isotope stratigraphy application to the late Quaternary. Paleoceanography, 1:137-162.

Ramanathan, V., Barkstrom, B.R., and Harrison, E.F., 1989. Climate and the Earth's radiation budget. Phys. Today, 42:22-32.

Raval, A., and Ramanathan, V., 1989. Observational determination of the greenhouse effect. Nature, 342:758-761.

Raymo, M.E., Ruddiman, W.F., Shackleton, N.J., and Oppo, D.W., 1990. Evolution of global ice volume and Atlantic-Pacific $\delta^{13} \mathrm{C}$ gradients over the last 2.5 m.y. Earth Planet. Sci. Lett., 97:353-368.

Reid, J.L., 1969. Sea-surface temperature, salinity and density of the Pacific Ocean in summer and in winter. Deep-Sea Res., Pt. A, 16 (Suppl.):215-224.

Ruddiman, W.F., McIntyre, A., and Raymo, M., 1986. Matuyama 41,000-year cycles: North Atlantic Ocean and Northern Hemisphere ice sheets. Earth Planet. Sci. Lett., 80:117-129.

Ruddiman, W.F., and Raymo, M.E., 1988. Northern Hemisphere climatic regimes during the past $3 \mathrm{Ma}$ : possible tectonic connections. Philos. Trans. R. Soc. London, Ser. B, 318:411-430.

Ruddiman, W.F., Raymo, M.E., Martinson, D.G., Clement, B.M., and Backman, J., 1989. Pleistocene evolution: Northern Hemisphere ice sheets and North Atlantic Ocean. Paleoceanography, 4:353-412.

Schiffelbein, P., 1984. Stable isotope systematics in Pleistocene deep-sea sediment records [Ph.D. dissert.]. Univ. of Calif., San Diego.

Shackleton, N.J., Berger, A., and Peltier, W.R., 1990. An alternative astronomical calibration of the lower Pleistocene timescale based on ODP Site 677. Trans. R. Soc. Edinburgh, Earth Sci., 81:251-261.

Shackleton, N.J., Imbrie, J., and Pisias, N.G., 1988. The evolution of oceanic oxygen-isotope variability in the North Atlantic over the past three million years. Philos. Trans. R. Soc. London, Ser. B, 318:679-688.

Shackleton, N.J., and Opdyke, N.D., 1973. Oxygen isotope and paleomagnetic stratigraphy of equatorial Pacific Core V28-238: oxygen isotope temperatures and ice volumes on a $10^{5}$ year and $10^{6}$ year scale. Quat. Res., 3:39-55. , 1976. Oxygen-isotope and paleomagnetic stratigraphy of Pacific Core V28-239: late Pliocene to latest Pleistocene. In Cline, R.M., and Hays, J.D. (Eds.), Investigations of Late Quaternary Paleoceanography and Paleoclimatology. Mem. Geol. Soc. Am., 145:449-464.

Shipboard Scientific Party, 1991. Site 806. In Kroenke, L.W., Berger, W.H., Janecek, T.R., et al., Proc. ODP, Init. Repts., 130: College Station, TX (Ocean Drilling Program), 291-367.

van Andel, T.H., Heath, G.R., and Moore, T.C., Jr., 1975. Cenozoic tectonics, sedimentation, and paleoceanography of the central equatorial Pacific. Mem. Geol. Soc. Am., 143.

Wefer, G., and Berger, W.H., 1991. Isotope paleontology: growth and composition of extant calcareous species. Mar. Geol., 100:207-248.

Whitman, J., and Berger, W.H., 1992. Pliocene-Pleistocene oxygen isotope record, Site 586, Ontong Java Plateau. Mar. Micropaleontol., 18:171-198.

Williams, D.F., Thunell, R.C., Tappa, E., Rio, D., and Raffi, I., 1988. Chronology of the Pleistocene oxygen-isotope record: 0-1.88 m.y.B.P. Palaeogeogr., Palaeoclimatol., Palaeoecol., 64:221-240.

Wu, G., and Berger, W.H., 1991. Pleistocene $\delta^{18} \mathrm{O}$ records from Ontong-Java Plateau: effects of winnowing and dissolution. Mar. Geol., 96:193-209.

Wu, G., Yasuda, M.K., and Berger, W.H., 1991. Late Pleistocene carbonate stratigraphy on Ontong-Java Plateau in the western equatorial Pacific. Mar. Geol., 99:135-150.

Date of initial receipt: 28 October 1991

Date of acceptance: 22 October 1992

Ms 130B-023 

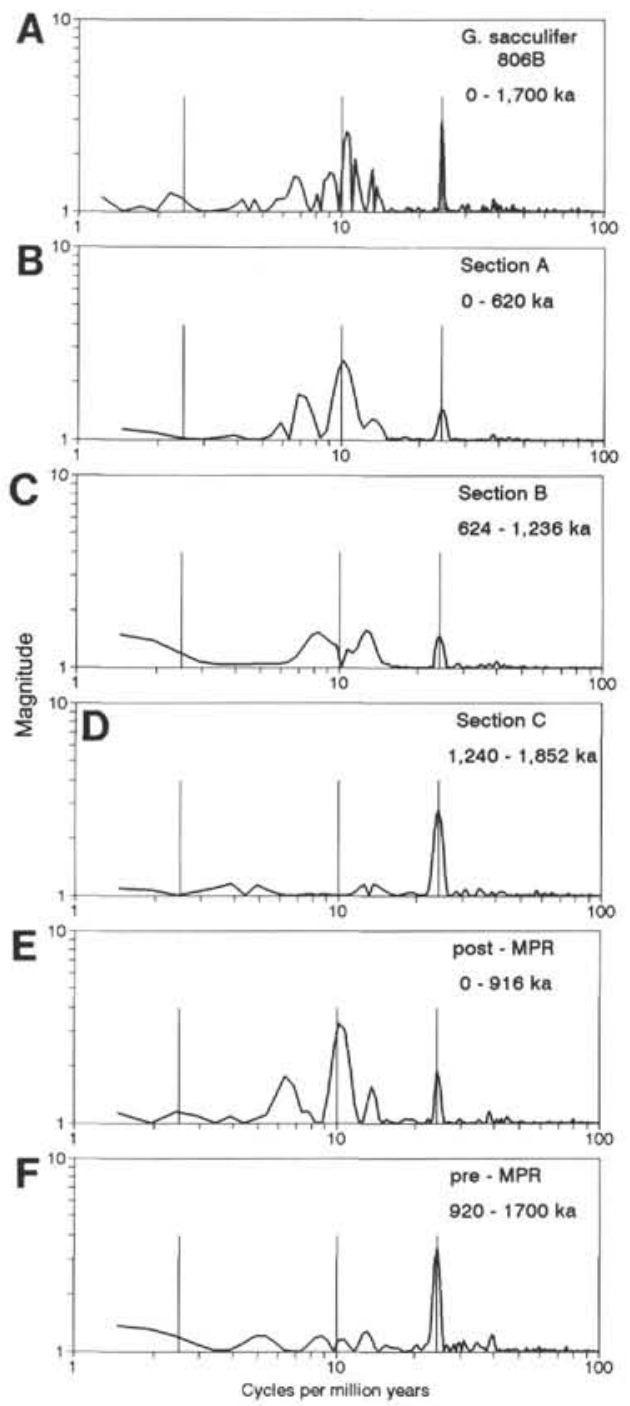

Figure 15. Spectra of sections of the Quaternary $\delta^{18} \mathrm{O}$ record of $G$. sacculifer, Hole 806B. A. Entire Quaternary. B. Last 15 obliquity cycles only (from Stage 16 to Stage 15 transition). C. Previous 15 obliquity cycles (o30 to Stage 16). D. Section between 30 th and 45 th obliquity cycles. E. Section between mid-Pleistocene climate shift (MPR) and present. F. Section between beginning of Pleistocene and MPR. "Magnitude" = the sum of squares of real and imaginary coefficients in the FFT expansion. The vertical lines indicate the positions of the periods 400,100 , and 41 k.y., for orientation.

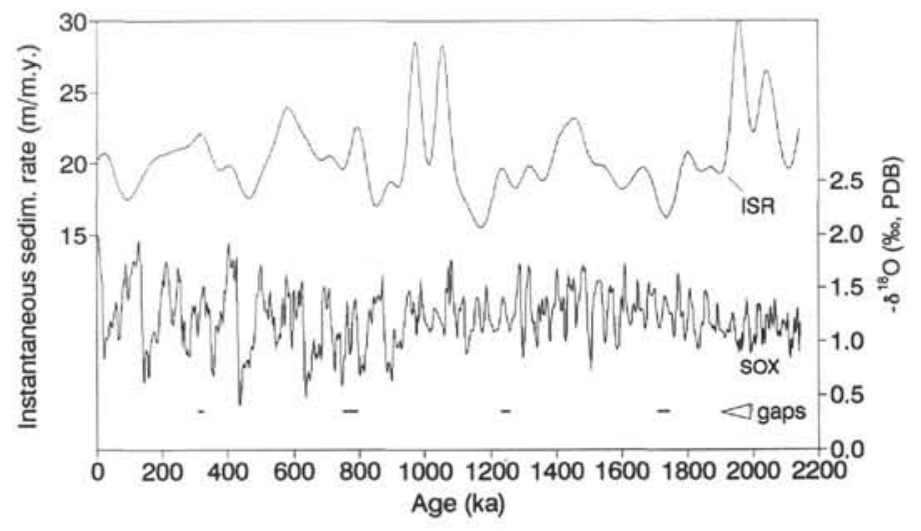

Figure 16. Comparison of the record of the instantaneous sedimentation rate (ISR), as derived from counting obliquity cycles, and the $\delta^{18} \mathrm{O}$ record of $G$. sacculifer (SOX) in Hole 806B. Gaps for core breaks are shown at the bottom of the graph.

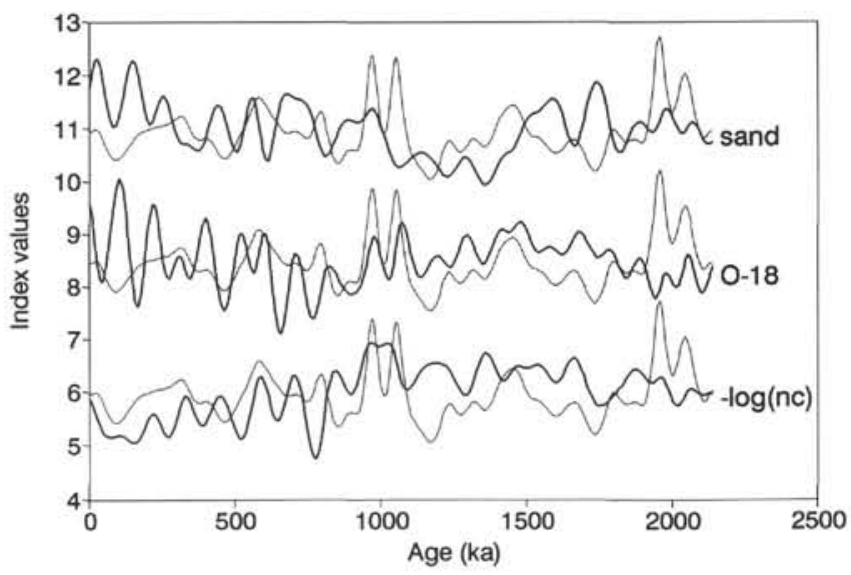

Figure 17. Comparison of record in Hole $806 \mathrm{~B}$ of instantaneous sedimentation rate (thin line) with three proxies of environmental change: sand content, $\delta^{18} \mathrm{O}$ of $G$. sacculifer, and carbonate content (expressed in terms of negative log of noncarbonate). Frequencies higher than 90 k.y. were removed. Index values are standardized and offset for clarity. Sand percentages are as listed in Yasuda et al. (this volume), and carbonate values are from T. Janecek (this volume).

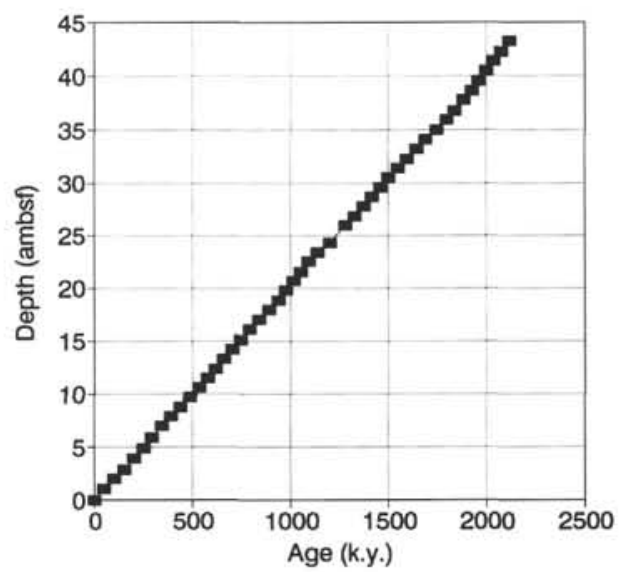

Figure 18. Age-depth plot in Hole $806 \mathrm{~B}$ for the last 2200 k.y., based on assignment of gaps and depth-conversion factors given in text, and on ages derived from counting obliquity cycles. ambsf $=$ adjusted meters below seafloor. 
Table 3. Depth and age assignments to ODPdepths in Cores 130-806B-1H through - $5 \mathrm{H}$.

\begin{tabular}{|c|c|c|c|c|}
\hline \multirow[b]{2}{*}{ Core } & \multicolumn{2}{|c|}{ Depth } & \multirow{2}{*}{$\begin{array}{l}\text { Age } \\
(\mathrm{ka})\end{array}$} & \multirow{2}{*}{$\begin{array}{c}\text { ISR } \\
(\mathrm{m} / \mathrm{m} . \mathrm{y} .)\end{array}$} \\
\hline & mbsf & ambsf & & \\
\hline $1 \mathrm{H}$ & 0 & 0.00 & 0.0 & 19.28 \\
\hline $1 \mathrm{H}$ & 1 & 0.97 & 47.6 & 19.28 \\
\hline $1 \mathrm{H}$ & 2 & 1.94 & 100.6 & 18.31 \\
\hline $1 \mathrm{H}$ & 3 & 2.89 & 152.5 & 19.22 \\
\hline $1 \mathrm{H}$ & 4 & 3.88 & 201.6 & 20.50 \\
\hline $1 \mathrm{H}$ & 5 & 4.85 & 248.1 & 20.97 \\
\hline $1 \mathrm{H}$ & 6 & 5.80 & 293.2 & 21.44 \\
\hline $2 \mathrm{H}$ & 7 & 6.95 & 346.0 & 20.82 \\
\hline $2 \mathrm{H}$ & 8 & 7.85 & 391.6 & 19.41 \\
\hline $2 \mathrm{H}$ & 9 & 8.75 & 438.8 & 18.50 \\
\hline $2 \mathrm{H}$ & 10 & 9.65 & 488.9 & 18.60 \\
\hline $2 \mathrm{H}$ & 11 & 10.55 & 535.5 & 20.73 \\
\hline $2 \mathrm{H}$ & 12 & 11.45 & 575.7 & 22.86 \\
\hline $2 \mathrm{H}$ & 13 & 12.35 & 614.3 & 22.42 \\
\hline $2 \mathrm{H}$ & 14 & 13.25 & 656.0 & 20.96 \\
\hline $2 \mathrm{H}$ & 15 & 14.15 & 700.2 & 20.39 \\
\hline $2 \mathrm{H}$ & 16 & 15.05 & 744.2 & 20.92 \\
\hline $3 \mathrm{H}$ & 16 & 16.10 & 793.4 & 20.97 \\
\hline $3 H$ & 17 & 17.01 & 837.7 & 18.88 \\
\hline $3 \mathrm{H}$ & 18 & 17.92 & 889.8 & 18.23 \\
\hline $3 \mathrm{H}$ & 19 & 18.83 & 937.5 & 21.42 \\
\hline $3 \mathrm{H}$ & 20 & 19.74 & 974.7 & 23.91 \\
\hline $3 \mathrm{H}$ & 21 & 20.65 & 1013.7 & 23.53 \\
\hline $3 \mathrm{H}$ & 22 & 21.56 & 1052.1 & 23.83 \\
\hline $3 \mathrm{H}$ & 23 & 22.47 & 1090.0 & 20.63 \\
\hline $3 \mathrm{H}$ & 24 & 23.38 & 1140.3 & 16.72 \\
\hline $3 \mathrm{H}$ & 25 & 24.29 & 1198.9 & 17.63 \\
\hline $4 \mathrm{H}$ & 26 & 25.90 & 1283.3 & 19.17 \\
\hline $4 \mathrm{H}$ & 27 & 26.81 & 1330.4 & 19.39 \\
\hline $4 \mathrm{H}$ & 28 & 27.72 & 1377.1 & 20.23 \\
\hline $4 \mathrm{H}$ & 29 & 28.63 & 1420.4 & 21.92 \\
\hline $4 \mathrm{H}$ & 30 & 29.54 & 1460.2 & 22.34 \\
\hline $4 \mathrm{H}$ & 31 & 30.45 & 1501.8 & 20.93 \\
\hline $4 \mathrm{H}$ & 32 & 31.36 & 1547.1 & 19.50 \\
\hline $4 \mathrm{H}$ & 33 & 32.27 & 1595.1 & 18.77 \\
\hline $4 \mathrm{H}$ & 34 & 33.18 & 1644.1 & 19.17 \\
\hline $4 \mathrm{H}$ & 35 & 34.09 & 1690.1 & 18.32 \\
\hline $5 \mathrm{H}$ & 35 & 35.00 & 1743.4 & 17.78 \\
\hline $5 \mathrm{H}$ & 36 & 35.91 & 1792.4 & 19.34 \\
\hline $5 \mathrm{H}$ & 37 & 36.82 & 1837.5 & 19.77 \\
\hline $5 \mathrm{H}$ & 38 & 37.73 & 1884.5 & 19.92 \\
\hline $5 \mathrm{H}$ & 39 & 38.64 & 1928.9 & 23.56 \\
\hline $5 \mathrm{H}$ & 40 & 39.55 & 1961.7 & 26.28 \\
\hline $5 \mathrm{H}$ & 41 & 40.46 & 1998.1 & 24.58 \\
\hline $5 \mathrm{H}$ & 42 & 41.37 & 2035.8 & 24.49 \\
\hline $5 \mathrm{H}$ & 43 & 42.28 & 2072.5 & 22.80 \\
\hline $5 \mathrm{H}$ & 44 & 43.19 & 2115.6 & 22.80 \\
\hline
\end{tabular}

Notes: ODP depths given in 1-m intervals. ISR $=$ instantaneous sedimentation rate at that depth, in m/m.y. 